\title{
Effects of injectable calcitriol on mineral metabolism and postpartum health and performance in dairy cows
}

\author{
A. Vieira-Neto, ${ }^{1,2}$ G. Negro, ${ }^{1}$ R. Zimpel,,${ }^{1,2}$ M. Poindexter, ${ }^{1}$ F. Lopes Jr., ${ }^{1}$ W. W. Thatcher, ${ }^{1,2}$ C. D. Nelson, ${ }^{1}$ \\ and J. E. P. Santos ${ }^{1 *}$ \\ ${ }^{1}$ Department of Animal Sciences, University of Florida, Gainesville 32611 \\ ${ }^{2} \mathrm{DH}$ Barron Reproductive and Perinatal Biology Research Program, University of Florida, Gainesville 32611
}

\begin{abstract}
Objectives were to determine the effects of an injectable formulation of calcitriol on Ca concentration, risk of clinical diseases, and performance in dairy cows. Cows were blocked by lactation number ( 1 vs. $>1$ ) and calving sequence and, within block, assigned randomly within $6 \mathrm{~h}$ of calving to receive subcutaneously vehicle only (CON, $\mathrm{n}=450)$ or $200(\mathrm{CAL} 200, \mathrm{n}=450)$ or 300 $\mu \mathrm{g}$ of $1 \alpha, 25$-dihydroxyvitamin $\mathrm{D}_{3}(\mathrm{CAL300}, \mathrm{n}=450)$. Cows were fed the same acidogenic diet prepartum. Blood was sampled before treatment administration and again during the first $11 \mathrm{~d}$ postpartum and analyzed for concentrations of ionized $\mathrm{Ca}$ (iCa), total $\mathrm{Ca}$ (tCa), $\mathrm{Mg}(\mathrm{tMg})$, and $\mathrm{P}(\mathrm{tP}), \beta$-hydroxybutyrate, carboxylated osteocalcin (cOC), and undercarboxylated osteocalcin (uOC). Cows were evaluated for diseases in the first $60 \mathrm{~d}$ postpartum. Reproduction and survival were monitored for the first $300 \mathrm{~d}$ postpartum. Calcitri$\mathrm{ol}$ increased concentration of blood $\mathrm{iCa}(\mathrm{CON}=1.12$ vs. CAL200 $=1.23$ vs. CAL300 $=1.27 \mathrm{mM}$ ), plasma $\mathrm{tCa}(\mathrm{CON}=2.29$ vs. $\mathrm{CAL} 200=2.44$ vs. $\mathrm{CAL} 300=$ $2.46 \mathrm{mM})$, and plasma tP $(\mathrm{CON}=1.72$ vs. CAL200 $=$ 2.21 vs. CAL300 $=2.28 \mathrm{mM}$ ), and differences were observed during the first $5 \mathrm{~d}$ postpartum for $\mathrm{iCa}$ and $\mathrm{tCa}$, and the first $7 \mathrm{~d}$ postpartum for tP. Concentrations of $\mathrm{tMg}$ were lower in calcitriol-treated cows than in CON cows $(\mathrm{CON}=0.81$ vs. CAL200 $=0.78$ vs. CAL300 $=$ $0.75 \mathrm{~m} M)$, and differences were observed during the first $5 \mathrm{~d}$ postpartum. Calcitriol increased plasma concentrations of $\mathrm{cOC}(\mathrm{CON}=14.5$ vs. $\mathrm{CAL} 200=23.0$ vs. $\mathrm{CAL} 300=19.8 \mathrm{ng} / \mathrm{mL})$ and $\mathrm{uOC}(\mathrm{CON}=1.6 \mathrm{vs}$. CAL200 $=3.4$ vs. CAL300 $=2.6 \mathrm{ng} / \mathrm{mL})$. Prevalence of subclinical hypocalcemia was less in calcitriol-treated cows $(\mathrm{CON}=19.0$ vs. CAL200 $=4.7$ vs. CAL300 $=$ $9.3 \%$ ); however, benefits on health were only observed in overconditioned cows $(n=270 / 1,350)$. Calcitriol re-
\end{abstract}

Received February 28, 2020.

Accepted August 10, 2020.

*Corresponding author: jepsantos@ufl.edu duced incidence of retained placenta $(\mathrm{CON}=14.3$ vs. CAL200 $=5.1$ vs. CAL300 $=5.9 \%$ ), puerperal metritis $(\mathrm{CON}=12.7$ vs. $\mathrm{CAL} 200=6.1$ vs. $\mathrm{CAL} 300=2.5 \%)$, and morbidity $(\mathrm{CON}=72.1$ vs. CAL200 $=57.4$ vs. CAL300 $=56.9 \%$ ) in cows with BCS greater than 3.50, but no benefit on health was observed in cows with BCS equal to or less than 3.50 at parturition. Milk yield did not differ among treatments. Pregnancy at first AI did not differ, but pregnancy rate after the first AI was slower for calcitriol-treated cows because of reduced insemination rate and pregnancy per AI. We found that CAL200 reduced death but increased culling in cows without calving problems. Collectively, results indicate that treatment with calcitriol at parturition was effective in improving concentrations of $\mathrm{iCa}$, tCa, and tP, which reduced the risk of hypocalcemia. Pregnancy rate was reduced by calcitriol treatment, and benefits on health performance were limited to overconditioned cows. Thus, treatment of all cows is not supported, and proper identification of cohorts of cows that benefit from postpartum interventions that increase blood calcitriol or calcium is needed.

Key words: calcitriol, dairy cow, health, hypocalcemia

\section{INTRODUCTION}

Colostrogenesis and onset of lactation result in sequestration of $\mathrm{Ca}$ into the mammary gland (Visek et al., 1953) and subsequent irreversible losses of $\mathrm{Ca}$ in colostrum and milk that influence $\mathrm{Ca}$ homeostasis (Ramberg et al., 1970; Goff et al., 2002). The lowest plasma Ca concentration occurs between 24 and $48 \mathrm{~h}$ after calving (Martinez et al., 2012), with the mean concentration of $\mathrm{Ca}$ being lowest within the first $30 \mathrm{~h}$ after calving (Megahed et al., 2018). It is postulated that the inability of dairy cows to promptly adapt the physiological mechanisms responsible for restoring blood ionized $\mathrm{Ca}$ (iCa), such as intestinal absorption, bone resorption, and urinary reabsorption of $\mathrm{Ca}$, results in hypocalcemia. A small proportion of those cows develop clinical hypocalcemia, whereas a large proportion 
develops subclinical hypocalcemia (SCH; Reinhardt et al., 2011).

Hypocalcemia is considered a gateway disease, because it predisposes cows to numerous others periparturient problems. In particular, clinical and subclinical hypocalcemia have been associated with dystocia (Curtis et al., 1983), retained placenta (Melendez et al., 2004), metritis (Martinez et al., 2012), and uterine prolapse (Risco et al., 1984). Smooth muscle contraction is reduced when $\mathrm{SCH}$ is induced, which impairs myometrial contractility (Al-Eknah and Noakes, 1989). Furthermore, extracellular Ca concentration has been shown to influence the intracellular $\mathrm{Ca}$ pool such that hypocalcemia results in lower cytosolic iCa concentration (Kimura et al., 2006; Martinez et al., 2014), which consequently impairs responsiveness of immune cells to a stimulus (Kimura et al., 2006). In dairy cows, induced $\mathrm{SCH}$ reduced cytosolic iCa concentrations and impaired neutrophil oxidative burst and phagocytic activity (Martinez et al., 2014), which are symptomatic of compromised innate immune function.

One dietary strategy to prevent hypocalcemia is manipulation of the DCAD of prepartum diets by incorporation of acidogenic products or salts (NAHMS, 2014). Acidogenic diets result in a compensated metabolic acidosis (Rodney et al., 2018), which improves Ca homeostasis, reduces hypocalcemia and other diseases, and improves lactation performance (Santos et al., 2019). Nevertheless, despite feeding acidogenic diets prepartum, the prevalence of SCH remains relatively high in early lactation (Martinez et al., 2016), indicating the need for complementary methods to further improve blood Ca concentrations in early lactation.

Vitamin D metabolites are important regulators of Ca metabolism, and, among them, 1 1 ,25-dihydroxyvitamin $\mathrm{D}_{3}$ is a potent calciotropic hormone (Vieira-Neto et al., 2017). When administered at a dose of $300 \mu \mathrm{g}$ at parturition in dairy cows, $1 \alpha, 25$-dihydroxyvitamin $\mathrm{D}_{3}$ has been found to increase concentrations of blood $\mathrm{iCa}$ and plasma total calcium (tCa; Vieira-Neto et al., 2017). The increase in blood concentrations of Ca resulting from exogenous $1 \alpha, 25$-dihydroxyvitamin $\mathrm{D}_{3}$ were sustained over several days with no indication of subsequent hypocalcemia (Kim et al., 2011; Vieira-

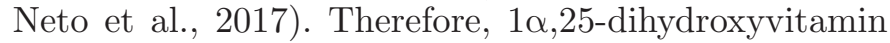
$\mathrm{D}_{3}$, at a small dose used immediately postpartum, does not seem to elicit a suppression of endogenous synthesis of $1 \alpha, 25$-dihydroxyvitamin $\mathrm{D}_{3}$ that could result in iatrogenic hypocalcemia (Goff et al., 1988). On the other hand, very large doses of vitamin $\mathrm{D}_{3}$, $375 \mathrm{mg}$, injected more than once, caused toxicity and death of cows (Littledike and Horst, 1982). When 300 $\mu \mathrm{g}$ of $1 \alpha, 25$-dihydroxyvitamin $\mathrm{D}_{3}$ was administered immediately after calving, measures of neutrophil func- tion improved in postpartum cows (Vieira-Neto et al., 2017). Therefore, it is possible that administration of exogenous $1 \alpha, 25$-dihydroxyvitamin $\quad \mathrm{D}_{3}$ immediately after calving might benefit performance in dairy cows because of the increased Ca availability and improved innate immune response. Furthermore, vitamin D metabolites affect bone metabolism and synthesis of bonederived hormones such as osteocalcin, which links bone metabolism with energy metabolism (Lee et al., 2007).

We hypothesized that an injectable formulation of 1 $\alpha, 25$-dihydroxyvitamin $\mathrm{D}_{3}$ administered at parturition would sustain increased concentrations of $\mathrm{Ca}$ in blood and would improve health, productive, and reproductive performance in dairy cows. Therefore, the objectives of the experiment were to determine the effect of an injectable formulation of $1 \alpha, 25$-dihydroxyvitamin $\mathrm{D}_{3}$ on the incidence of $\mathrm{SCH}$ and clinical diseases, and on productive and reproductive performance in dairy cows.

\section{MATERIALS AND METHODS}

The University of Florida (Gainesville) Institutional Animal Care and Use Committee approved all procedures involving animals in the current experiment under protocol number 201408679.

\section{Cows, Housing, and Diets}

A total of 1,350 Holstein cows, 354 primiparous and 996 multiparous cows from a commercial dairy farm located in north central Florida, were enrolled in this experiment between September 2016 and January 2017. The last cow completed the 300-d observation period in November 2017. The lactating herd was composed of approximately 5,000 milking cows during the experiment, with a rolling herd average of $11,700 \mathrm{~kg}$ of milk.

A sample size was calculated using the POWER procedure of SAS (SAS/STAT version 9.4; SAS Institute Inc., Cary, NC). The main assumption was that a reduction in hypocalcemia would result in reduced incidence of metritis (Martinez et al., 2012). We have previously shown that calcitriol reduced the daily prevalence of $\mathrm{SCH}$ in the first $3 \mathrm{~d}$ postpartum from 56.6 to $6.8 \%$ in dairy cows (Vieira-Neto et al., 2017). Based on the reduction in $\mathrm{SCH}$ and the association between $\mathrm{SCH}$ and metritis, a 10-percentage unit reduction in metritis was anticipated with calcitriol treatment (e.g., 35 vs. 25\%). Because 3 treatments were implemented, a 2 -sided sample size was calculated, adjusting $\alpha$ to 0.017 $(0.05 / 3)$ to allow for adjustment of multiple comparisons after Bonferroni adjustment. Therefore, the sample size calculated $(\alpha=0.017 ; \beta=0.20)$ resulted in 438 cows per treatment. A total of 450 cows per treatment 
were enrolled in the experiment. For $\mathrm{iCa}$, the sample size calculated, as previously described $(\alpha=0.017 ; \beta$ $=0.20$ ), assumed a difference between treatments of $0.20 \mathrm{~m} M$ and a standard deviation (SD) of $0.15 \mathrm{mM}$ (Vieira-Neto et al., 2017). Twenty-eight experimental units were deemed necessary; thus, 30 were used, 10 per treatment.

Cows were housed in barns with sand-bedded stalls equipped with sprinklers and fans for heat abatement. Primiparous and multiparous cows were housed in separate pens during the pre- and postpartum periods. Prepartum nulliparous and parous cows were fed the same diet as TMR for ad libitum intake, formulated to have a negative DCAD to minimize the risk of hypocalcemia. Urinary $\mathrm{pH}$ was not monitored and recorded by the research team routinely; nevertheless, sporadic urine samples were collected and analyzed for $\mathrm{pH}$ to ensure that the prepartum diet fed resulted in metabolic acidosis. Postpartum primiparous and multiparous cows were fed an early-lactation diet as TMR to meet the nutrient requirements of a Holstein cow weighing $650 \mathrm{~kg}$ and producing $33 \mathrm{~kg}$ of $3.5 \% \mathrm{FCM} / \mathrm{d}$ when DMI is $20 \mathrm{~kg} / \mathrm{d}$ in the first $21 \mathrm{~d}$ postpartum (NRC, 2001; Table 1).

Approximately $2 \mathrm{~kg}$ of TMR was collected weekly and dried in a forced-air oven at $55^{\circ} \mathrm{C}$ for $48 \mathrm{~h}$, and moisture loss was recorded. Each sample was individually ground to pass through a $1.0-\mathrm{mm}$ mesh screen, and composites were prepared every $4 \mathrm{wk}$ with equal amounts of each weekly sample. Monthly samples were analyzed for OM $\left(512^{\circ} \mathrm{C}\right.$ for $\left.8 \mathrm{~h}\right), \mathrm{NDF}$ using heat stable $\alpha$-amylase, $\mathrm{ADF}$ with the Ankom Fiber Analyzer system (Ankom Technology, Macedon, NY), N using an automated quantitative combustion digestion method (Leco 628, Leco Corp., St. Joseph, MO), starch using an enzymatic digestion method, and subsequent quantification of glucose and fat by acid hydrolysis. Minerals were analyzed using inductively coupled plasma mass spectrometry at a commercial laboratory (Dairyland Laboratories Inc., Arcadia, WI). The ingredient composition and nutrient content of the diets offered to pre- and postpartum cows are shown in Table 1.

\section{Formulations of Vehicle and Calcitriol}

The vehicle and calcitriol formulations were prepared as described previously by Vieira-Neto et al. (2017). Briefly, a stock solution of $1 \alpha, 25$-dihydroxyvitamin $\mathrm{D}_{3}$ was prepared by dissolving $10 \mathrm{mg}$ of crystalline powder 1 $\alpha, 25$-dihydroxyvitamin $\mathrm{D}_{3}$ (BOC Sciences, Shirley, $\mathrm{NY}$ ) in $1 \mathrm{~mL}$ of ethanol 99.5\% (Sigma-Aldrich, St. Louis, MO). The concentration of 1 1 ,25-dihydroxyvitamin $\mathrm{D}_{3}$ in the stock solution was verified by UV absorbance between 200 and 300 nm (BioTek Synergy HT; BioTek
Instruments, Winooski, VT) to ensure proper dilution and then stored at $-20^{\circ} \mathrm{C}$.

Once weekly, the vehicle was prepared by diluting $750 \mu \mathrm{g}$ of 2,6-di-tert-butyl-4-methylphenol (SigmaAldrich), which was added as an antioxidant, into 100 $\mathrm{mL}$ of glyceryl troctanoate (Sigma-Aldrich). Vehicle was used to dilute the stock solution containing $1 \alpha, 25-$ dihydroxyvitamin $\mathrm{D}_{3}$. Five hundred microliters of stock solution was diluted in $99.5 \mathrm{~mL}$ of vehicle to obtain a final working solution containing $50 \mu \mathrm{g} / \mathrm{mL} 1 \alpha, 25$ dihydroxyvitamin $\mathrm{D}_{3}$, which was used as one of the treatments in the experiment. A portion of the $50 \mu \mathrm{g} /$ $\mathrm{mL}$ working solution was further diluted 2 to 1 with vehicle ( $\mathrm{vol} / \mathrm{vol}$ ), to result in a second working solution containing $33.3 \mu \mathrm{g} / \mathrm{mL} 1 \alpha, 25$-dihydroxyvitamin $\mathrm{D}_{3}$. All procedures were performed aseptically under a laminar flow hood using autoclaved materials. Working solutions containing vehicle only or 33.3 and $50 \mu \mathrm{g} /$ $\mathrm{mL} 1 \alpha, 25$-dihydroxyvitamin $\mathrm{D}_{3}$ were stored at $8^{\circ} \mathrm{C}$ and used within $7 \mathrm{~d}$.

\section{Experimental Design and Treatments}

The experiment followed a randomized block design. Cows were blocked by parity as lactation 1 or lactation greater than 1 postpartum and, within parity group, by sequence of calving. Randomization sheets were generated separately for primiparous and multiparous cows. For each parity group, the randomization sheets were generated with blocks to accommodate 3 cows each, such that each treatment was represented once in each block. As primiparous and multiparous cows calved, they were allocated to the respective randomization sheets in blocks, according to sequence of calving, to receive the treatments that were administered within the first $6 \mathrm{~h}$ postpartum. Treatments were administered subcutaneously in the ischiorectal fossa and consisted of $6 \mathrm{~mL}$ of vehicle only (CON; 450 cows, 118 primiparous and 332 multiparous), $6 \mathrm{~mL}$ of a solution containing $33.3 \mu \mathrm{g} / \mathrm{mL} 1 \alpha, 25$-dihydroxyvitamin $\mathrm{D}_{3}$ to deliver a total of $200 \mu \mathrm{g}$ of calcitriol (CAL200; 450 cows, 118 primiparous and 332 multiparous), or $6 \mathrm{~mL}$ of a solution containing $50 \mu \mathrm{g} / \mathrm{mL} 1 \alpha, 25$-dihydroxyvitamin $\mathrm{D}_{3}$ to deliver a total of $300 \mu \mathrm{g}$ of calcitriol (CAL300; 450 cows, 118 primiparous and 332 multiparous). Authors were not blinded to treatments.

The farm was visited twice daily (0600 and $1800 \mathrm{~h}$ ) to identify cows that were in labor or that had just calved. The farm staff recorded the moment of calving for all cows in the experiment, and only those in labor or that were within the first $6 \mathrm{~h}$ of calving were eligible for enrollment in the experiment. Of the 1,350 cows enrolled, 198 were in labor and received the treatments before delivering the calf (CON: 16 primiparous 
Table 1. Ingredient composition and nutrient content of pre- and postpartum diets

\begin{tabular}{|c|c|c|}
\hline \multirow[b]{2}{*}{ Item } & \multicolumn{2}{|c|}{$\operatorname{Diet}^{1}$} \\
\hline & Prepartum & Postpartum \\
\hline \multicolumn{3}{|l|}{ Ingredient, $\%$ of DM } \\
\hline Corn silage & 39.1 & 35.7 \\
\hline Sorghum silage & 18.7 & - \\
\hline Oat hay & 14.8 & 4.9 \\
\hline Triticale silage & - & 4.9 \\
\hline Corn grain, finely ground & 10.9 & 3.1 \\
\hline Canola meal, solvent extract & 1.5 & 20.2 \\
\hline Soybean meal, solvent extract & 1.8 & 2.4 \\
\hline Brewers grains, wet & 5.2 & 6.1 \\
\hline Cane molasses & 1.1 & 3.5 \\
\hline Acidogenic product ${ }^{2}$ & 1.7 & - \\
\hline Prepartum mineral-vitamin protein mix $^{3}$ & 5.2 & - \\
\hline Corn earlage & - & 7.9 \\
\hline Soy hulls & - & 2.0 \\
\hline Citrus pulp & - & 2.2 \\
\hline Saturated free fatty acids ${ }^{4}$ & - & 0.4 \\
\hline Fermented whey, $40 \% \mathrm{CP}^{5}$ & - & 1.3 \\
\hline Lactation mineral-vitamin protein $\operatorname{mix}^{6}$ & - & 5.4 \\
\hline \multicolumn{3}{|l|}{ Nutrient content, DM basis $( \pm \mathrm{SD})$} \\
\hline $\mathrm{NE}_{\mathrm{L}},{ }^{7} \mathrm{Mcal} / \mathrm{kg}$ & 1.51 & 1.63 \\
\hline $\mathrm{OM}, \%$ & $91.6 \pm 0.4$ & $90.2 \pm 1.7$ \\
\hline $\mathrm{CP}, \%$ & $14.3 \pm 0.4$ & $18.6 \pm 0.5$ \\
\hline $\mathrm{MP}, \%$ & 8.9 & 10.5 \\
\hline NDF, $\%$ & $42.7 \pm 1.7$ & $33.3 \pm 1.9$ \\
\hline $\mathrm{NFC}, 8 \%$ & $33.8 \pm 1.2$ & $37.5 \pm 1.8$ \\
\hline Ether extract, \% & $2.6 \pm 0.2$ & $4.1 \pm 0.1$ \\
\hline $\mathrm{Ca}, \%$ & $1.62 \pm 0.14$ & $1.13 \pm 0.10$ \\
\hline $\mathrm{P}, \%$ & $0.41 \pm 0.01$ & $0.41 \pm 0.01$ \\
\hline $\mathrm{Mg}, \%$ & $0.41 \pm 0.01$ & $0.35 \pm 0.01$ \\
\hline K. \% & $1.19 \pm 0.10$ & $1.46 \pm 0.01$ \\
\hline S, $\%$ & $0.28 \pm 0.01$ & $0.27 \pm 0.01$ \\
\hline $\mathrm{Na}, \%$ & $0.11 \pm 0.01$ & $0.58 \pm 0.03$ \\
\hline $\mathrm{Cl}, \%$ & $0.97 \pm 0.04$ & $0.44 \pm 0.08$ \\
\hline $\mathrm{DCAD},{ }^{9} \mathrm{mEq} / \mathrm{kg}$ & $-98 \pm 20$ & $337 \pm 7$ \\
\hline
\end{tabular}

${ }^{1}$ Prepartum diet was fed from $255 \mathrm{~d}$ of gestation to calving, and postpartum diet from calving to $21 \mathrm{~d}$ postpartum. Means and SD of 5 composite samples.

${ }^{2}$ Animate (Phibro Animal Health Corporation, Teaneck, NJ).

${ }^{3}$ Contained $53.3 \%$ calcium carbonate, $13.7 \%$ ammonium chloride, $8.2 \%$ monocalcium phosphate, $6.2 \%$ magnesium oxide, $3.4 \%$ sodium chloride, $5.5 \%$ vitamin and trace minerals mixture, $6 \%$ urea, $2.1 \%$ DiaMune Se (Diamond V, Cedar Rapids, IA), 0.9\% Rumensin 100 diluted to $4.5 \%$ sodium monensin (Elanco Animal Health, Greenfield, IN), and 0.7\% vitamin E premix containing $500 \mathrm{kIU} / \mathrm{kg}$. Each kilogram contained $39.9 \%$ CP, $23.1 \% \mathrm{Ca}, 1.9 \% \mathrm{P}, 3.6 \% \mathrm{Mg}, 0.1 \% \mathrm{~K}, 1.6 \% \mathrm{Na}, 11.4 \% \mathrm{Cl}, 0.2 \% \mathrm{~S}, 2,500 \mathrm{mg}$ of $\mathrm{Zn}, 520 \mathrm{mg}$ of Cu, 1,600 mg of Mn, $17.9 \mathrm{mg}$ of Se, $56.0 \mathrm{mg}$ of Co, $29.4 \mathrm{mg}$ of I, 466,400 IU of vitamin A, 112,400 IU of vitamin D, 10,500 IU of vitamin $\mathrm{E}$, and $400 \mathrm{mg}$ of monensin.

${ }^{4}$ Energy Booster Mag (Milk Specialties, Eden Prairie, MN).

${ }^{5}$ LactoWhey 40 (Fermented Nutrition Corporation, Luxemburg, WI).

${ }^{6}$ Contained $55.4 \%$ soybean hulls, $13.3 \%$ sodium bicarbonate, $9.9 \%$ calcium carbonate, $2.2 \%$ sodium chloride, $1.4 \%$ magnesium oxide, $4.4 \%$ potassium carbonate (DCAD Plus, Arm and Hammer Animal and Food Production, Princeton, NJ), $0.2 \%$ Availa 4 (Zinpro Performance Minerals, Eden Prairie, MN), $0.7 \%$ vitamin and trace minerals premix (Suwannee Valley Feeds, Trenton, FL), $4.2 \%$ urea, $5.0 \%$ prilled saturated free fatty acids (Energy Booster, Milk Specialties, Eden Prairie, MN), 2.0\% molasses, 0.7\% calcium 2-hydroxy-4-(methylthio)butanoate (MHA 84\%, methionine analog, Novus International, St. Charles, MO), 0.4\% DiaMune Se (Diamond V, Cedar Rapids, IA), and 0.2\% Rumensin 100 (Elanco Animal Health, Greenfield, IN). Each kilogram contained $19.5 \% \mathrm{CP}, 4.8 \% \mathrm{Ca}, 0.1 \% \mathrm{P}, 1.1 \% \mathrm{Mg}, 3.4 \% \mathrm{~K}, 5.3 \% \mathrm{Na}, 1.4 \% \mathrm{Cl}, 0.1 \% \mathrm{~S}, 722 \mathrm{mg}$ of Zn, $155 \mathrm{mg}$ of $\mathrm{Cu}, 444 \mathrm{mg}$ of Mn, $4.4 \mathrm{mg}$ of Se, $15 \mathrm{mg}$ of Co, $8.3 \mathrm{mg}$ of I, 133,500 IU of vitamin A, 32,500 IU of vitamin D, 1,070 IU of vitamin E, and $200 \mathrm{mg}$ of monensin.

${ }^{7}$ Calculated using NRC (2001), according to the chemical composition of the dietary ingredients and adjusted for 11 and $20 \mathrm{~kg}$ of DM intake for the pre- and postpartum periods, respectively.

${ }^{8}$ Calculated as follows: NFC $=\mathrm{DM}-($ ash $+\mathrm{CP}+$ ether extract $+\mathrm{NDF}-\mathrm{NDF}$ insoluble CP $)$.

${ }^{9}$ Calculated as follows: $\mathrm{DCAD}=[(\mathrm{mEq}$ of $\mathrm{K})+(\mathrm{mEq}$ of $\mathrm{Na})]-[(\mathrm{mEq}$ of $\mathrm{Cl})+(\mathrm{mEq}$ of $\mathrm{S})]$. 
and 46 multiparous; CAL200: 20 primiparous and 51 multiparous; and CAL300: 19 primiparous and 46 multiparous). The mean $( \pm \mathrm{SD})$ time of treatment relative to calving in those cows was $-118.9 \pm 137.9 \mathrm{~min}$. The remaining 1,152 cows received the treatments within the first $6 \mathrm{~h}$ after calving, which averaged $192.0 \pm 117.8$ min after calving.

\section{Blood Collection, Processing, and Laboratory Analyses}

Blood was sampled from all cows by puncture of the coccygeal vessels into lithium-heparinized evacuated tubes (Vacutainer; Becton Dickinson, Franklin Lakes, NJ) immediately before administration of treatments and again on d 1, 2, and 3 postpartum. Blood was sampled from all cows again on d 4 and 8 postpartum into evacuated tubes containing $\mathrm{K}_{2}$ EDTA (Vacutainer; Becton Dickinson). Tubes were placed on ice and transported to the laboratory for processing within 3 h. Tubes were centrifuged at $2,500 \times g$ for $20 \mathrm{~min}$ for plasma separation. Plasma samples were transferred into microtubes and stored at $-20^{\circ} \mathrm{C}$ until analyses. Samples collected on d 0, 1, 2, and 3 postpartum were analyzed for concentrations of tCa, total P (tP) as inorganic phosphate, and total $\mathrm{Mg}(\mathbf{t M g})$. Samples collected on d 4 and 8 were analyzed for concentrations of BHB.

Blood also was sampled into lithium-heparinized evacuated tubes from a subset of 55 randomly selected blocks (165 cows) immediately before administration of treatments and again on d 1, 2, 3, 4, 5, 7, 9, and 11 postpartum. Samples were processed as previously indicated, and plasma was analyzed for concentrations

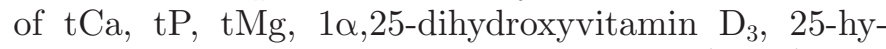
droxyvitamin $\mathrm{D}_{3}$, carboxylated osteocalcin (cOC), and undercarboxylated osteocalcin (uOC).

Another 10 randomly selected blocks of cows including 30 cows had blood sampled immediately before treatment and again on $\mathrm{d} 1,2,3$, and 5 postpartum. These samples were analyzed for concentrations of iCa using a hand-held biochemical analyzer (i-Stat; Abbott Laboratories, Princeton, NJ).

Plasma was analyzed for concentrations of tMg (xylidyl-blue method) and tP (phosphomolybdate method) using a biochemical analyzer (RX Daytona, Randox, Crumlin, UK). Intra- and interassay CV were, respectively, $1.9 \%$ and $8.1 \%$ for $\mathrm{tCa}, 3.6 \%$ and $10.2 \%$ for $\mathrm{tMg}$, and $0.9 \%$ and $9.8 \%$ for $\mathrm{tP}$.

Concentrations of BHB in plasma were analyzed by a colorimetric method (Wako Autokit 3-HBt; Wako Diagnostics Inc., Mountain View, CA). The intra- and interassay CV were 1.9 and $5.6 \%$. Concentrations of
$1 \alpha, 25$-dihydroxyvitamin $\mathrm{D}_{3}$ in plasma were analyzed by ELISA $\left[1 \alpha, 25(\mathrm{OH})_{2}\right.$ Vitamin D ELISA; IBL-America, Minneapolis, MN] according to the manufacturer's instructions and previously used by Vieira-Neto et al. (2017). The intra- and interassay CV were 1.6 and $11.8 \%$, respectively. Concentrations of 25-hydroxyvitamin $\mathrm{D}_{3}$ in plasma were analyzed by ELISA [25(OH) Vitamin D ELISA, DRG Instruments GmbH, Marburg, Germany] as per manufacturer's instructions, except that a custom standard prepared in bovine serum was used in place of the standard provided with the kit (Nelson et al., 2016). The intra- and interassay CV were 5.9 and $10.2 \%$, respectively. Concentrations of cOC (Gla-Type Osteocalcin EIA Kit, Clontech Labs, Takara Bio Inc., Mountain View, CA) and uOC (GluType Osteocalcin EIA Kit, Clontech Labs, Takara Bio Inc.) were analyzed via ELISA. The intra- and interassay CV were, respectively, 3.4 and $10.7 \%$ for cOC and 4.4 and $9.1 \%$ for uOC.

\section{Diagnosis of Clinical Diseases, Body Condition, and Milk Yield}

The farm staff recorded calving information, which included sex of the calf, singleton or twin birth, stillbirth, and dystocia. Every morning, the research team evaluated cows for presence of fetal membranes. Diagnosis of retained placenta was based on failure to release the placenta in the morning following calving; therefore, cows with retained placenta were those that did not shed the placenta within 12 to $24 \mathrm{~h}$ after calving. On the same morning after calving, the vulva-vagina was inspected for diagnosis of laceration, as previously described (Vieira-Neto et al., 2016).

Vaginal discharge was evaluated using the Metricheck device (Simcro Tech Ltd., Hamilton, New Zealand) on $\mathrm{d} 4,6$, and 8 postpartum and scored as previously reported (McLaughlin et al., 2012): 1 = no discharge observed; 2 = not fetid, normal lochia, viscous, red, brown, or clear; $3=$ not fetid, thick mucus, cloudy, clearing, or clear; $4=$ not fetid, may be purulent or mucopurulent, brown; and $5=$ fetid, thin, serous, or watery, red or brown color, with or without pieces of necrotic tissue present. Vaginal discharge scored as 5 was classified as metritis. Every cow diagnosed with metritis had rectal temperature measured, and those with temperature $\geq 39.5^{\circ} \mathrm{C}$ were classified as having fever. Cows with metritis and fever were considered to have puerperal metritis. Additionally, cows diagnosed with metritis had vaginal discharge and rectal temperature re-evaluated 5,7 , and $12 \mathrm{~d}$ after the day of the diagnosis to determine metritis cure. Cure of metritis was defined as vaginal discharge score less than 5 . Cows 
with metritis were treated by the farm staff with 6.6 $\mathrm{mg}$ of ceftiofur free acid per $\mathrm{kg}$ of BW $(200 \mathrm{mg} / \mathrm{mL}$, Excede, Zoetis, Parsippany, NJ), administered on the day of diagnosis and again 3 d later. Farm employees were blinded to treatments.

Vaginal discharge was evaluated again at $35 \pm 3 \mathrm{~d}$ postpartum using the Metricheck device for the diagnosis of purulent vaginal discharge (PVD) as previously described (LeBlanc et al., 2002): 1 = clear mucus or translucent mucus; $2=$ cloudy mucus with flecks of pus; $3=$ mucopurulent, at least $50 \%$ mucus and less than $50 \%$ pus present; $4=$ purulent, $>50 \%$ pus present; $5=$ purulent or red-brown and foul smelling. Cows with a vaginal discharge score of 3 or greater were considered as having PVD. Incidence of mastitis, lameness, respiratory disease (fever, increased respiratory frequency, and detection of wheeze, rhonchi, or crackle sounds at auscultation), displaced abomasum (based on auscultation and percussion of the left or right flank, followed by confirmation during corrective surgery), or other digestive problems (diarrhea or bloat) in the first $60 \mathrm{~d}$ postpartum were recorded for each individual cow by the farm staff, following farm standard operating protocols for diagnosis and therapy. Morbidity included diagnosis of at least one disease event that included retained placenta, metritis, mastitis, lameness, digestive problem, displaced abomasum, or respiratory disease in the first 60 DIM.

Body condition was evaluated by the same person on the day of calving and again at $35 \pm 3$ and $70 \pm 3 \mathrm{~d}$ postpartum, using a scoring system from 1 (emaciated) to 5 (obese) as previously described (Elanco Animal Health, 2009). Cows were milked thrice daily, and milk yield was recorded once a month for each cow during the first $300 \mathrm{~d}$ of lactation.

For statistical analyses, the body condition of cows at calving was categorized as low $(\mathrm{BCS} \leq 2.75)$, moderate (BCS between 3.00 and 3.50), or high (BCS >3.50). The number of cows with low, moderate, or high BCS at calving were, respectively, 37, 317, and 96 in CON; 42, 323, and 85 in CAL200; and 43, 318, and 89 in CAL 300. Moreover, cows were categorized as having or not having calving problems based on the diagnosis of 1 or more of the following disorders: dystocia, stillbirth, twin, retained placenta, or vulvovaginal laceration. The number of cows with or without calving problems were, respectively, 173 and 277 in CON, 178 and 272 in CAL200, and 179 and 271 in CAL300.

\section{Definitions of Subclinical Diseases}

Subclinical hypocalcemia and hyperketonemia were evaluated. Two distinct thresholds were selected to define incidence of SCH: plasma tCa $\leq 2.00 \mathrm{~m} M$ (Reinhardt et al., 2011) or tCa $<2.15 \mathrm{~m} M$ (Martinez et al., 2012). However, because very few cows had plasma tCa $\leq 2.00$ after $3 \mathrm{~d}$ postpartum, the daily prevalence of $\mathrm{SCH}$ in the first $11 \mathrm{~d}$ postpartum was evaluated only with the $2.15 \mathrm{~m} M$ threshold for plasma tCa. Incidence of SCH was based on at least 1 sample with plasma concentration of tCa below the threshold on $\mathrm{d}$ 1,2 , or 3 postpartum. Hyperketonemia was defined as plasma BHB concentration $>1.20 \mathrm{~m} M$. Prevalence of hyperketonemia was based on at least 1 sample with plasma concentration above the threshold on d 4 or 8 postpartum.

\section{Evaluation of Estrous Cyclicity and Reproductive Management}

Ovaries were scanned by ultrasound (Easi-Scan, BCS Technology, Livingston, UK) on d $35 \pm 3$ and $49 \pm 3$ postpartum. Presence of a corpus luteum with diameter of at least $20 \mathrm{~mm}$ on at least 1 of the 2 examinations indicated resumption of ovulation (Bicalho et al., 2008).

Cows had their estrous cycle synchronized using the double Ovsynch protocol (Souza et al., 2008) starting on d $54 \pm 3$ postpartum. Cows received the first postpartum $\mathrm{AI}$ on $\mathrm{d} 81 \pm 3$ postpartum. Following the first AI, cows had their tailheads painted daily with chalk after the morning milking. Cows observed to be in estrus, based on removal of chalk, were inseminated in the same morning. Reinseminated cows were considered as nonpregnant to the previous AI. Pregnancy was diagnosed by ultrasonography on d $32 \pm 3$ after AI, based on visualization of an amniotic vesicle with an embryo. Pregnant cows on d 32 were re-evaluated for pregnancy 4 wk later, at $60 \pm 3 \mathrm{~d}$ after AI. Nonpregnant cows were enrolled in the Ovsynch protocol for reinsemination. Pregnancy per AI was calculated by dividing the number of cows diagnosed pregnant at 32 or $60 \mathrm{~d}$ after AI by the number of cows that received AI. Pregnancy loss was calculated by dividing the number of cows that lost pregnancy between 32 and $60 \mathrm{~d}$ of gestation by the number of pregnant cows on d 32 after AI. Reproductive data were collected until a cow was confirmed pregnant on d 60 after AI, or when the farm manager decided to no longer breed the cow, or if the cow was culled or died. For analysis of interval from calving to pregnancy, the diagnosis on d 60 after AI was used as the indicator of pregnancy.

\section{Statistical Analyses}

Continuous data were analyzed with linear mixed models using the MIXED procedure of SAS. The resid- 
uals were evaluated for distribution and homogeneity of variance after fitting the statistical models.

The statistical model for continuous data with repeated measures within experimental unit included the fixed effects of treatment (CON vs. CAL200 vs. CAL300), parity group postpartum (1 vs. >1), BCS category at calving (low vs. moderate vs. high), calving problem (no vs. yes), day postpartum, and the interactions between treatment and parity, treatment and BCS category, treatment and calving problem, and treatment and day, and the random effects of block and cow nested within treatment. Analyses of concentrations of minerals and hormones in blood included the values on d 0 , before administration of treatments, that were used as covariates in the statistical models. Nonsignificant interactions $(P>0.10)$ were removed sequentially by backward elimination based on the largest $P$-value. The Repeated statement was used to model within-subject variation, the covariance structure that best fitted the data was used, and model fit was assessed based on the smallest corrected Akaike's information criterion. For equally-spaced data, first-order autoregressive structure was the most common covariance structure. For unequally-spaced data, spatial power covariance structure was selected. The Kenward-Roger method was used to calculate the approximate denominator degrees of freedom for the $F$ tests in the statistical models.

Continuous data with a single measurement per cow, such as cumulative milk yield in the first 60 or $300 \mathrm{~d}$ postpartum, were analyzed using mixed models, including the fixed effects of treatment, parity group postpartum, BCS category at calving, calving problem, and the interactions between treatment and parity, treatment and BCS category, and treatment and calving problem, and the random effect of block. Nonsignificant interactions $(P>0.10)$ were removed sequentially by backward elimination, based on the largest $P$-value. The Kenward-Roger method was used to calculate the approximate denominator degrees of freedom for the $F$ tests in the statistical models.

Categorical data were analyzed by logistic regression using generalized linear mixed models with the GLIMMIX procedure of SAS, fitting a binary distribution. The model included the fixed effects of treatment, parity prepartum, BCS category, calving problem, and the interactions between treatment and parity, treatment and BCS category, and treatment and calving problem, and the random effect of block. Nonsignificant interactions $(P>0.10)$ were removed sequentially by backward elimination based on the largest $P$-value. The Kenward-Roger method was used to calculate the approximate denominator degrees of freedom for the $F$ tests in the statistical models. For prevalence of $\mathrm{SCH}$, the statistical model also included the fixed effects of day and the interaction between treatment and day, and the random effect of cow nested within treatment.

Time to pregnancy and removal from the herd were analyzed with Cox's hazard regression method using the PHREG procedure of SAS. The statistical model included the fixed effects of treatment, parity, BCS category, calving problem, and the interactions between treatment and parity, treatment and BCS category, and treatment and calving problem. Nonsignificant interactions $(P>0.10)$ were removed sequentially by backward elimination based on the largest $P$-value.

Pre-planned orthogonal contrasts were used to evaluate the effects of calcitriol administration (CON vs. CAL200 + CAL300) and the effect of dose of calcitriol administered (CAL200 vs. CAL300). Statistical significance was considered at $P \leq 0.05$ and tendency when $0.05<P \leq 0.10$.

\section{RESULTS}

\section{Concentrations of Vitamin D Metabolites in Plasma}

Treatment with calcitriol within $6 \mathrm{~h}$ of parturition increased $(P<0.001)$ the concentration of $1 \alpha, 25-$ dihydroxyvitamin $\mathrm{D}_{3}$ in plasma within $24 \mathrm{~h}$, which remained elevated until d 3 postpartum compared with CON cows (Figure 1A). Primiparous cows had smaller $(P<0.01)$ concentrations of $1 \alpha, 25$-dihydroxyvitamin $\mathrm{D}_{3}$ than did multiparous cows (primiparous $=79.9$; multiparous $=98.7 \pm 5.2 \mathrm{pg} / \mathrm{mL}$ ). Plasma concentration of 25-hydroxyvitamin $\mathrm{D}_{3}$ tended $(P=0.10)$ to be lower for calcitriol-treated cows and also tended to be lower $(P=0.08)$ for cows receiving CAL300 than for those receiving CAL200 (Figure 1B). Least squares means were $43.9,42.7$, and $38.8 \pm 2.0 \mathrm{ng} / \mathrm{mL}$ for CON, CAL200, and CAL300, respectively.

\section{Concentrations of iCa in Blood and Total Ca, $M g$, and $P$ in Plasma}

Pretreatment concentrations of iCa did not differ among treatments; however, calcitriol-treated cows had greater $(P<0.001)$ concentrations of iCa in blood compared with $\mathrm{CON}$, and the differences increased on d 2, 3, and 5 postpartum (Figure 2A). Dose of calcitriol did not affect concentration of iCa. Parity group did not affect concentrations of iCa in blood (primiparous $=1.20$ vs. multiparous $=1.21 \pm 0.02 \mathrm{mM}$ ).

Concentration of tCa in plasma increased $(P<$ 0.001 ) with calcitriol $24 \mathrm{~h}$ after treatment and remained elevated until d 5 postpartum (Figure 2B). On d 11, calcitriol-treated cows had reduced $(P<0.05)$ 

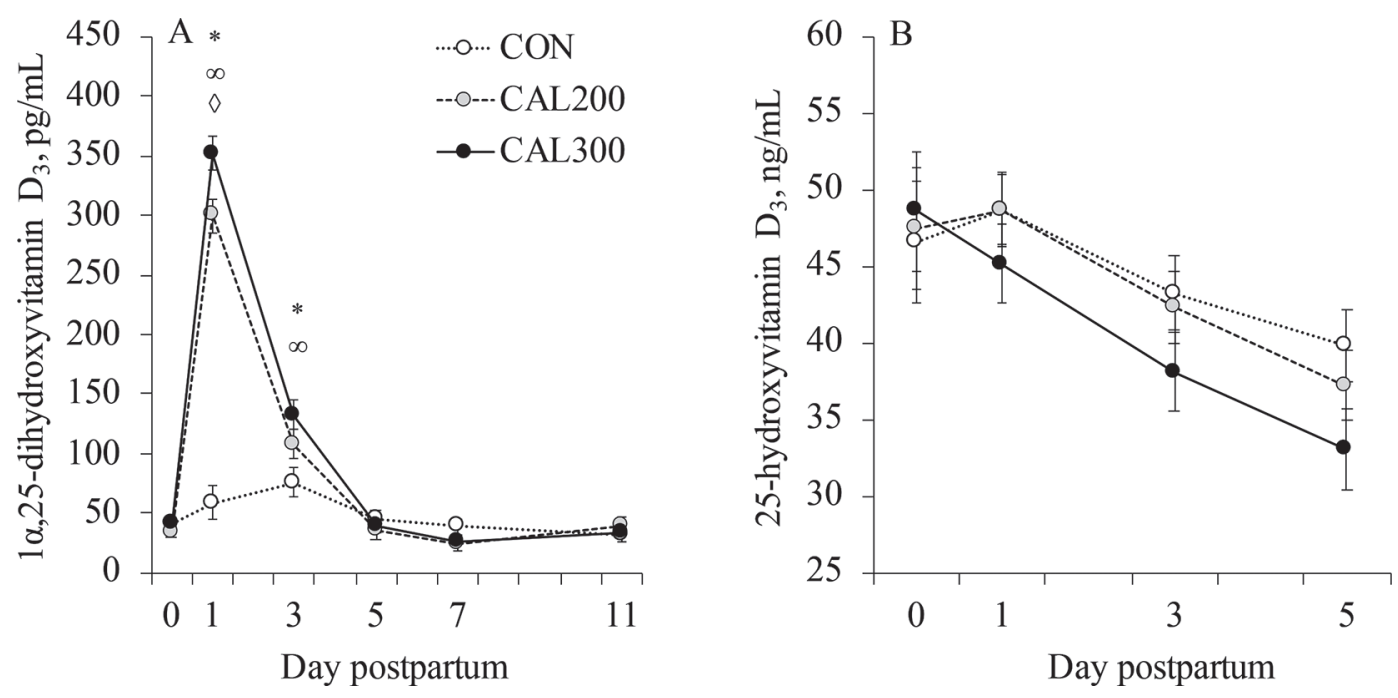

Figure 1. Concentrations of $1 \alpha, 25$-dihydroxyvitamin $\mathrm{D}_{3}(\mathrm{~A})$ and 25 -hydroxyvitamin $\mathrm{D}_{3}(\mathrm{~B})$ in plasma of dairy cows receiving an injection of $0(\mathrm{CON} ; \mathrm{n}=10), 200($ CAL200; $\mathrm{n}=10)$, or $300 \mu \mathrm{g}($ CAL300; $\mathrm{n}=10)$ of $1 \alpha, 25$-dihydroxyvitamin $\mathrm{D}_{3}$ at calving. (A) Effects of calcitriol $(P<$ $0.001)$, dose of calcitriol $(P=0.03)$, day $(P<0.001)$, and interaction between treatment and day $(P<0.001)$. (B) Effects of calcitriol $(P=0.10)$, dose of calcitriol $(P=0.08)$, day $(P<0.001)$, and interaction between treatment and day $(P=0.90)$. *Within day, CON differs from CAL200 $(P$ $<0.05) . \infty$ Within day, CON differs from CAL300 $(P<0.05)$. $\diamond$ Within day, CAL200 differs from CAL300 $(P<0.05)$. Values on d 0 represent the means before treatment administration and were used as covariates. Error bars depict SEM. The pooled SEM for 1 $\alpha, 25-$ dihydroxyvitamin $\mathrm{D}_{3}$ and 25-hydroxyvitamin $\mathrm{D}_{3}$ were 8.2 and 2.8 , respectively.

concentration of tCa in plasma compared with $\mathrm{CON}$ cows. Parity group did not affect concentrations of tCa in plasma (primiparous $=2.41$ vs. multiparous $=2.38$ $\pm 0.02 \mathrm{~m} M)$.

Treatment with calcitriol reduced $(P=0.005)$ the concentration of $\mathrm{tMg}$ in plasma starting the day following treatment until $5 \mathrm{~d}$ postpartum, after which differences were no longer present (Figure 2C). We detected an interaction between treatment and parity $(P<0.001)$ for concentrations of tMg because treatment with calcitriol reduced $(P<0.05)$ concentrations of $\mathrm{tMg}$ in primiparous compared with $\mathrm{CON}(\mathrm{CON}=$ 0.83 vs. $\mathrm{CAL} 200=0.80$ vs. $\mathrm{CAL} 300=0.70 \pm 0.03$ $\mathrm{m} M$ ), but no effect was observed in multiparous cows $(\mathrm{CON}=0.80$ vs. $\mathrm{CAL} 200=0.77$ vs. $\mathrm{CAL} 300=0.80$ $\pm 0.02 \mathrm{~m} M)$.

Concentrations of tP in plasma increased (effect of day, $P<0.001)$ in all cows the day after calving, but the increment was greater $(P<0.001)$ in cows treated with calcitriol (Figure 2D). Responses in plasma tP to calcitriol treatment did not differ between CAL200 and CAL300 cows, and the concentrations remained elevated compared with CON cows in the first $7 \mathrm{~d}$ postpartum. An interaction $(P=0.004)$ between treatment and parity was detectable for plasma tP, because the increment in plasma concentrations with calcitriol treatment were greater in primiparous $(\mathrm{CON}=1.68$ vs. CAL200 $=2.30$ vs. CAL300 $=2.39 \pm 0.07 \mathrm{mM}$ ) than in multiparous cows $(\mathrm{CON}=1.77$ vs. CAL200 $=2.13$ vs. CAL300 $=2.18 \pm 0.04 \mathrm{mM})$.

\section{Daily Prevalence of SCH}

Throughout the experiment, none of the cows presented symptoms of clinical hypocalcemia or milk fever. The prevalence of $\mathrm{SCH}$, based on plasma tCa $<2.15$ $\mathrm{m} M$, did not differ among treatments and affected $20 \%$ of the cows at parturition, before treatment administration (Figure 3). The daily prevalence of SCH was less $(P<0.001)$ in calcitriol-treated compared with $\mathrm{CON}$ cows in the first $5 \mathrm{~d}$ postpartum, after which they no longer differed (Figure 3).

\section{Incidence of Diseases}

Subclinical Diseases. Incidence of SCH based on tCa $<2.00 \mathrm{~m} M$ or $<2.15 \mathrm{~m} M$ were both reduced $(P<$ 0.001 ) by calcitriol (Table 2). Increasing the dose of calcitriol from CAL200 to CAL300 had a minor effect on incidence of $\mathrm{SCH}$. Although calcitriol reduced the incidence of $\mathrm{SCH}$ in cows at all BCS categories, an interaction $(P=0.05)$ between treatment and BCS was observed for $\mathrm{SCH}$ (Figure 4). The reduction in incidence of SCH with CAL200 and CAL300 was greater in cows with moderate and high BCS than that observed in cows with low BCS. Primiparous cows had lower 

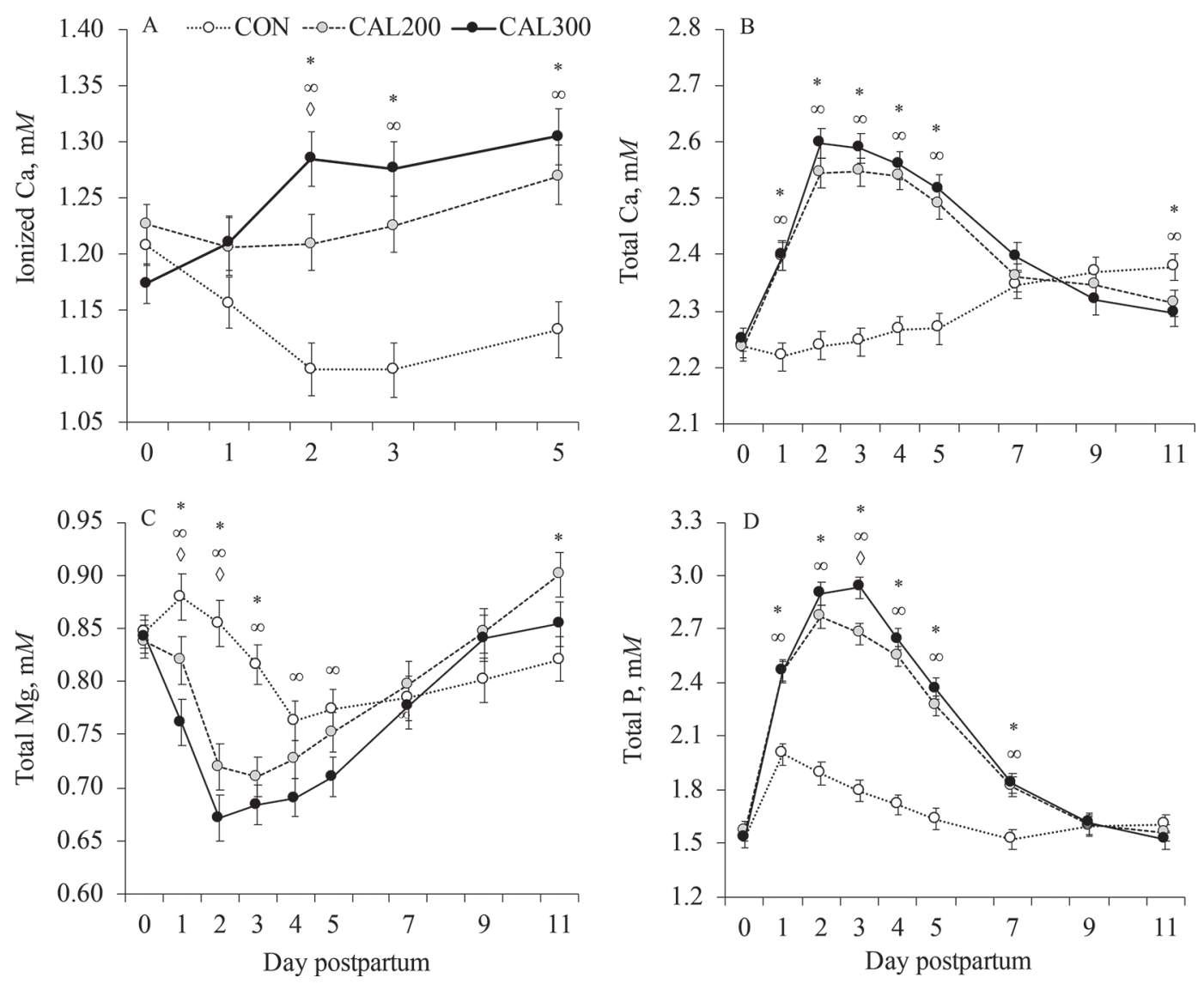

Figure 2. Concentrations of ionized $\mathrm{Ca}$ in whole blood (A), and total $\mathrm{Ca}(\mathrm{B})$, total $\mathrm{Mg}(\mathrm{C})$, and total $\mathrm{P}$ (D) in plasma of dairy cows receiving an injection of $0(\mathrm{CON} ; \mathrm{n}=55), 200(\mathrm{CAL} 200 ; \mathrm{n}=55)$, or $300 \mu \mathrm{g}($ CAL300; $\mathrm{n}=55)$ of $1 \alpha, 25$-dihydroxyvitamin $\mathrm{D}_{3}$ at calving. (A) Effects of calcitriol $(P<0.001)$, dose of calcitriol $(P=0.13)$, day $(P=0.08)$, and interaction between treatment and day $(P=0.006)$. (B) Effects of calcitriol $(P<0.001)$, dose of calcitriol $(P=0.41)$, day $(P<0.001)$, and interaction between treatment and day $(P<0.001)$. $(C)$ Effects of calcitriol $(P=0.005)$, dose of calcitriol $(P=0.06)$, day $(P<0.001)$, and interaction between treatment and day $(P<0.001)$. (D) Effects of calcitriol $(P<0.001)$, dose of calcitriol $(P=0.17)$, day $(P<0.001)$, and interaction between treatment and day $(P<0.001)$. ${ }^{*}$ Within day, CON differs from CAL200 $(P<0.05)$. $\infty$ Within day, CON differs from CAL300 $(P<0.05)$. $\diamond$ Within day, CAL200 differs from CAL300 $(P<0.05)$. Values on d 0 represent the means before treatment implementation and were used as covariates. Error bars depict SEM. The pooled SEM for ionized $\mathrm{Ca}$, total $\mathrm{Ca}$, total $\mathrm{Mg}$, and total $\mathrm{P}$ were, respectively, $0.02,0.03,0.02$, and 0.06 .

$(P<0.001)$ incidence of SCH than multiparous cows (primiparous $=12.8$ vs. multiparous $=27.9 \pm 2.1 \%$ ).

Hyperketonemia on $\mathrm{d} 4$ and 8 postpartum affected $9.6 \%(130 / 1,350)$ of the cows, and treatment had no effect on hyperketonemia (Table 2). A smaller $(P<$ 0.001) proportion of primiparous than multiparous cows had hyperketonemia (primiparous $=1.2$ vs. multiparous $=12.8 \pm 1.1 \%)$. Moreover, a greater $(P<$ 0.001) proportion of overconditioned than cows with moderate or low BCS had hyperketonemia (low $=2.2$ vs. moderate $=3.5$ vs. high $=8.0 \pm 1.3 \%$ ).

Clinical Diseases. Retained placenta affected $7.1 \%$ $(96 / 1,350$; Table 2$)$ of the cows, and a tendency $(P=$ 0.08 ) for an interaction between treatment and BCS was detected for retained placenta (Figure 4). In cows with high BCS, treatment with calcitriol reduced $(P$
$=0.05)$ the incidence of retained placenta compared with $\mathrm{CON}(\mathrm{CON}=14.4$ vs. $\mathrm{CAL} 200=5.1$ vs. CAL300 $=5.9 \pm 2.9 \%$; Figure $4 \mathrm{C}$ ), but no differences among treatments were observed in cows with low or moderate body condition.

Metritis was diagnosed in $49.7 \%(176 / 354)$ of the primiparous and $17.9 \%(178 / 996)$ of the multiparous cows. Treatment did not affect the incidence of metritis (Table 2). Puerperal metritis was diagnosed in $19.2 \%$ $(68 / 354)$ of the primiparous and $4.2 \%(42 / 996)$ of the multiparous cows. An interaction $(P=0.04)$ between treatment and BCS was observed for puerperal metritis (Figure 4). Calcitriol reduced $(P=0.05)$ the incidence of puerperal metritis in cows with high BCS (Figure $4 \mathrm{C}$ ), but it had no effect on cows with low or moderate BCS. Treatment with calcitriol did not affect cure of 


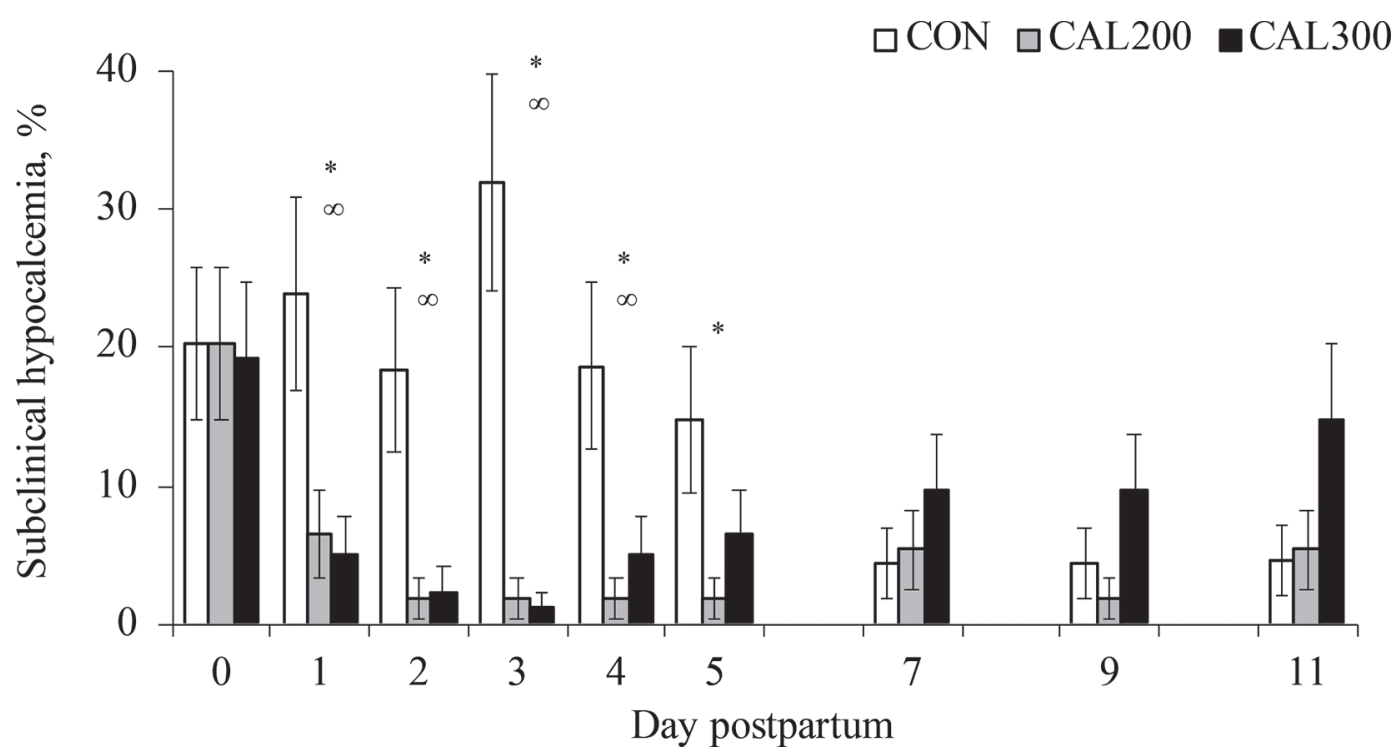

Figure 3. Daily prevalence of subclinical hypocalcemia (total $\mathrm{Ca}<2.15 \mathrm{~m} M$ ) in dairy cows receiving an injection of $0(\mathrm{CON} ; \mathrm{n}=55)$, 200 $($ CAL200; $\mathrm{n}=55)$, or $300 \mu \mathrm{g}($ CAL300; $\mathrm{n}=55)$ of $1 \alpha, 25$-dihydroxyvitamin $\mathrm{D}_{3}$ at calving. Day 0 represents the prevalence immediately before administration of treatment and was used as a covariate during statistical analysis. Effects of calcitriol $(P<0.001)$, dose of calcitriol $(P=0.05)$, day $(P=0.51)$, and interaction between treatment and day $(P<0.001) .{ }^{*}$ Within day, CON differs from CAL200 $(P<0.05) ; \infty \mathrm{CON}$ differs from CAL300 $(P<0.05)$. Values on d 0 represent the means before treatment implementation and were used as covariates. Error bars depict SEM. The pooled SEM for prevalence of subclinical hypocalcemia was 3.6.

metritis, and by $12 \mathrm{~d}$ after the diagnosis, 87.9, 83.1, and $85.2 \pm 4.1 \%$ of the CON, CAL200, and CAL300 cows had been considered cured for metritis.
Purulent vaginal discharge was diagnosed in $25.8 \%$ $(335 / 1,299)$ of the cows, and an interaction $(P=0.02)$ between treatment and calving problem was observed

Table 2. Effect of treatment on health in the first $60 \mathrm{~d}$ postpartum and removal from the herd by $300 \mathrm{~d}$ postpartum

\begin{tabular}{|c|c|c|c|c|c|c|c|c|}
\hline \multirow[b]{2}{*}{ Item, $\%$} & \multicolumn{3}{|c|}{ Treatment $^{1}$} & \multirow[b]{2}{*}{ SEM } & \multicolumn{4}{|c|}{$P$-value ${ }^{2}$} \\
\hline & $\mathrm{CON}$ & CAL200 & CAL300 & & TRT & TRT $\times$ parity & $\mathrm{C} 1$ & $\mathrm{C} 2$ \\
\hline \multicolumn{9}{|l|}{ Subclinical hypocalcemia ${ }^{3}$} \\
\hline $\mathrm{tCa}<2.00 \mathrm{~m} M$ & 15.7 & 2.8 & 1.5 & 1.3 & $<0.001$ & 0.65 & $<0.001$ & 0.09 \\
\hline $\mathrm{tCa}<2.15 \mathrm{~m} M^{*}$ & 51.4 & 10.9 & 9.1 & 2.5 & $<0.001$ & 0.23 & $<0.001$ & 0.47 \\
\hline Hyperketonemia $^{4}$ & 8.0 & 10.2 & 11.0 & 1.7 & 0.29 & 0.83 & 0.13 & 0.69 \\
\hline \multicolumn{9}{|l|}{ Clinical diseases } \\
\hline Puerperal metritis* & 6.1 & 5.8 & 6.6 & 1.9 & 0.42 & 0.77 & 0.99 & 0.78 \\
\hline Purulent vaginal discharge $\diamond$ & 25.9 & 31.3 & 31.5 & 2.9 & 0.18 & 0.17 & 0.06 & 0.96 \\
\hline Mastitis $\oint$ & 23.5 & 23.4 & 25.6 & 2.9 & 0.82 & 0.39 & 0.77 & 0.58 \\
\hline Lameness & 7.6 & 6.4 & 8.6 & 1.5 & 0.39 & 0.74 & 0.90 & 0.17 \\
\hline Other diseases ${ }^{5}$ & 11.5 & 13.4 & 12.9 & 1.9 & 0.70 & 0.44 & 0.42 & 0.82 \\
\hline Morbidity $^{6 *}$ & 69.7 & 62.1 & 64.3 & 3.4 & 0.24 & 0.33 & 0.11 & 0.62 \\
\hline Culling $\diamond$ & 6.1 & 8.9 & 9.7 & 1.6 & 0.11 & 0.78 & 0.04 & 0.68 \\
\hline
\end{tabular}

${ }^{1} \mathrm{CON}=$ cows received $0 \mu \mathrm{g}$ of $1 \alpha, 25$-dihydroxyvitamin $\mathrm{D}_{3}$ at calving $(\mathrm{n}=450)$; CAL200 $=$ cows received 200 $\mu \mathrm{g}$ of $1 \alpha, 25$-dihydroxyvitamin $\mathrm{D}_{3}$ at calving $(\mathrm{n}=450)$; CAL300 $=$ cows received $300 \mu \mathrm{g}$ of $1 \alpha, 25$-dihydroxyvitamin $\mathrm{D}_{3}$ at calving $(\mathrm{n}=450)$.

${ }^{2} \mathrm{TRT}=$ treatment. $\mathrm{C} 1=$ effect of calcitriol (CON vs. CAL200 + CAL300); C2 = effect of level of calcitriol (CAL200 vs. CAL300).

${ }^{3}$ Plasma total $\mathrm{Ca}(\mathrm{tCa})$ concentration $<2.00$ or $<2.15 \mathrm{~m} M$ in at least $1 \mathrm{~d}$ from 1 to $3 \mathrm{~d}$ postpartum.

${ }^{4}$ Plasma BHB concentration $>1.20 \mathrm{~m} M$ on $\mathrm{d} 4$ or 8 postpartum.

${ }^{5}$ Includes digestive problems, displaced abomasum, and respiratory disease.

${ }^{6}$ Includes retained placenta, metritis, mastitis, lameness, digestive problems, displaced abomasum, and respiratory disease.

$* P<0.05$ and $\S P<0.10$ for the interaction between treatment and body condition at calving.

$\diamond P<0.05$ for the interaction between treatment and calving problem (dystocia, stillbirth, twins, retained placenta, or vulvovaginal laceration). 

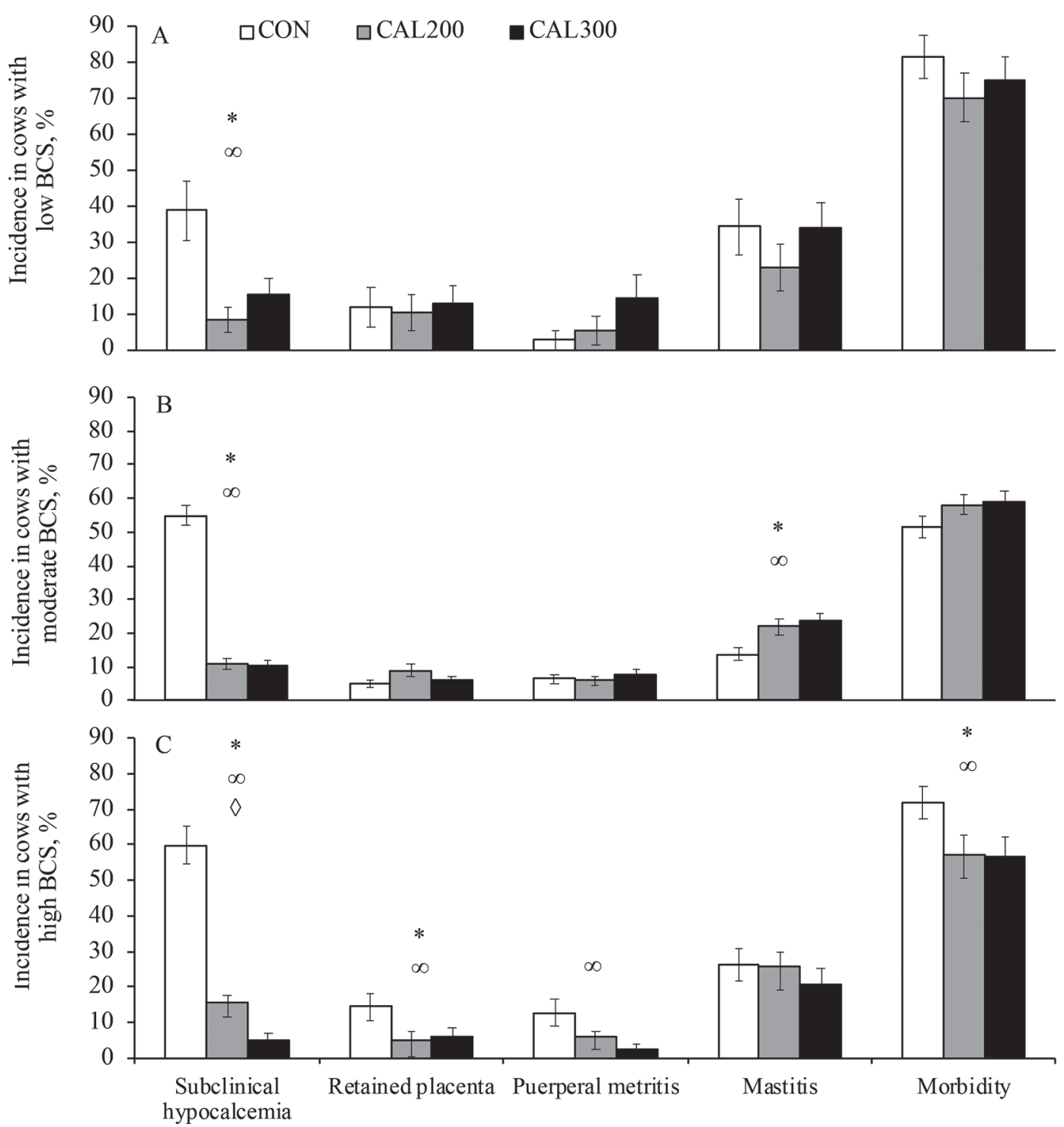

Figure 4. Incidence of subclinical hypocalcemia (total $\mathrm{Ca}<2.15 \mathrm{mM}$ ), retained placenta, puerperal metritis, mastitis, and morbidity by 60 d postpartum according to BCS category at calving. (A) Cows with BCS $<3.00(\mathrm{n}=122$ ); (B) cows with BCS between 3.00 and 3.50 ( $\mathrm{n}=$ 958); $(\mathrm{C})$ cows with BCS $>3.50(\mathrm{n}=270)$. Cows received an injection of $0(\mathrm{CON} ; \mathrm{n}=450), 200(\mathrm{CAL} 200 ; \mathrm{n}=450)$, or $300 \mu \mathrm{g}(\mathrm{CAL} 300 ; \mathrm{n}=$ $450)$ of $1 \alpha, 25$-dihydroxyvitamin $\mathrm{D}_{3}$ at calving. ${ }^{*}$ Within panel, CON differs from CAL200 $(P<0.05) ; \infty$ CON differs from CAL300 $(P<0.05)$. Error bars depict SEM. The pooled SEM for subclinical hypocalcemia, retained placenta, puerperal metritis, mastitis, and morbidity were, respectively, 3.8, 3.2, 2.9, 4.7, and 4.8 .

for PVD (Figure 5). In cows with calving problems, those in CAL200 had greater incidence of PVD than CON or CAL300; however, for cows without calving problems, those in CAL300 had greater incidence than CON or CAL200. Primiparous had greater $(P<0.001)$ incidence of PVD than multiparous cows (primiparous $=37.5$ vs. multiparous $=22.6 \pm 2.6 \%$ ).

Mastitis was diagnosed in $22.3 \%(301 / 1,350)$ of the cows, and a tendency $(P=0.06)$ for an interaction between treatment and BCS was observed for mastitis.
Treatment had no effect on incidence of mastitis in cows with low or high BCS at calving, but within cows with moderate BCS, those treated with calcitriol had increased $(P=0.01)$ incidence of mastitis compared with $\mathrm{CON}$ cows $(\mathrm{CON}=13.7$ vs. $\mathrm{CAL} 200=22.1$ vs. CAL300 $=23.5 \pm 2.2 \%$; Figure $6 \mathrm{~B})$.

Lameness affected $9.6 \%(130 / 1,350)$ of the cows, and treatment did not affect the incidence of lameness (Table 2). Primiparous cows had lower $(P=$ 0.04 ) incidence of lameness than did multiparous cows 

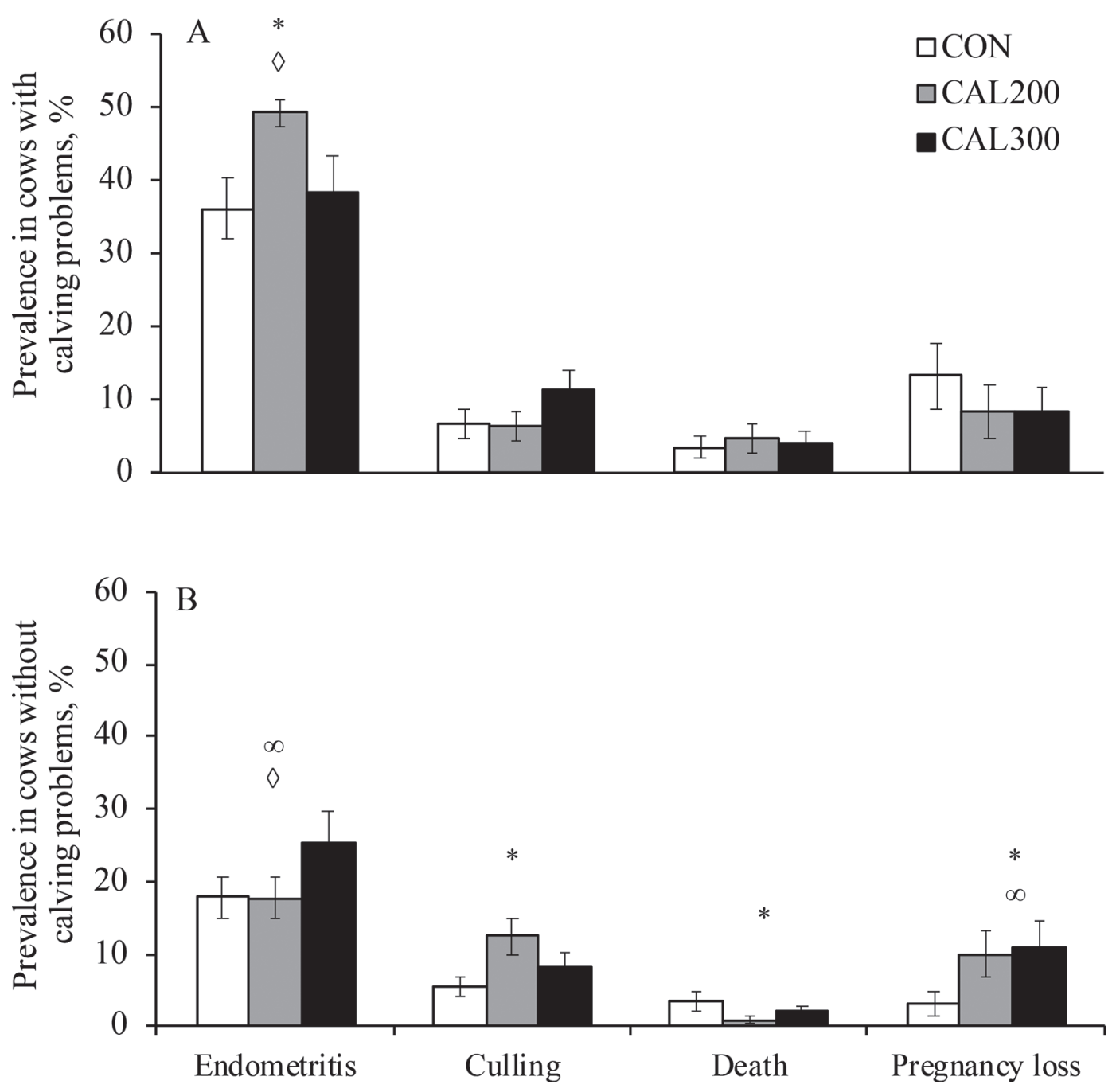

Figure 5. Prevalence of purulent vaginal discharge (PVD) and incidence of culling, death, and pregnancy loss at first AI according to treatment in cows diagnosed with calving problem (A; dystocia, stillbirth, twins, retained placenta, or vulvovaginal laceration) or cows not diagnosed with calving problem (B). Cows received an injection of $0(\mathrm{CON} ; \mathrm{n}=450), 200$ (CAL200; $\mathrm{n}=450)$, or 300 $\mu \mathrm{g}(\mathrm{CAL} 300 ; \mathrm{n}=450)$ of $1 \alpha, 25-$ dihydroxyvitamin $\mathrm{D}_{3}$ at calving. ${ }^{*}$ Within panel, CON differs from CAL200 $(P<0.05) ; \infty$ CON differs from CAL300 $(P<0.05) ; \diamond$ CAL200 differs from CAL300 $(P<0.05)$. Error bars depict SEM. The pooled SEM for PVD, culling, death, and pregnancy loss were, respectively, 3.5, $2.0,1.3$, and 3.4 .

(primiparous $=5.8$ vs. multiparous $=9.5 \pm 1.3 \%$ ) Other diseases, such as digestive problems, displaced abomasum, and respiratory disease, affected $11.3 \%$ $(152 / 1,350)$ of the cows enrolled in the experiment. Treatment with calcitriol did not affect the incidence of other diseases (Table 2).

Morbidity affected $53.9 \%(727 / 1,350)$ of the cows, and an interaction $(P=0.02)$ between treatment and BCS was observed for morbidity. For cows with low or moderate BCS, treatment did not affect morbidity; however, in cows with high BCS, treatment with calcitriol reduced $(P=0.04)$ morbidity compared with $\mathrm{CON}(\mathrm{CON}=72.1$ vs. $\mathrm{CAL} 200=57.4$ vs. $\mathrm{CAL} 300=$ $56.9 \pm 5.2 \%$; Figure 4C). Primiparous cows had greater
$(P<0.001)$ morbidity than multiparous cows (primiparous $=71.4$ vs. multiparous $=59.0 \pm 2.5 \%$ )

\section{Removal from the Herd}

By 300 DIM, 9.8\% $(133 / 1,350)$ of the cows were culled from the herd (Table 2$)$. An interaction $(P=0.05)$ between treatment and calving problem was observed for culling because, for cows with calving problems, treatment did not affect culling; however, in cows without calving problems, CAL200 increased culling compared with CON (Figure 5B). Culling was less $(P=0.01)$ in primiparous than multiparous cows (primiparous $=6.0$ vs. multiparous $=10.9 \pm 1.4 \%$ ). 

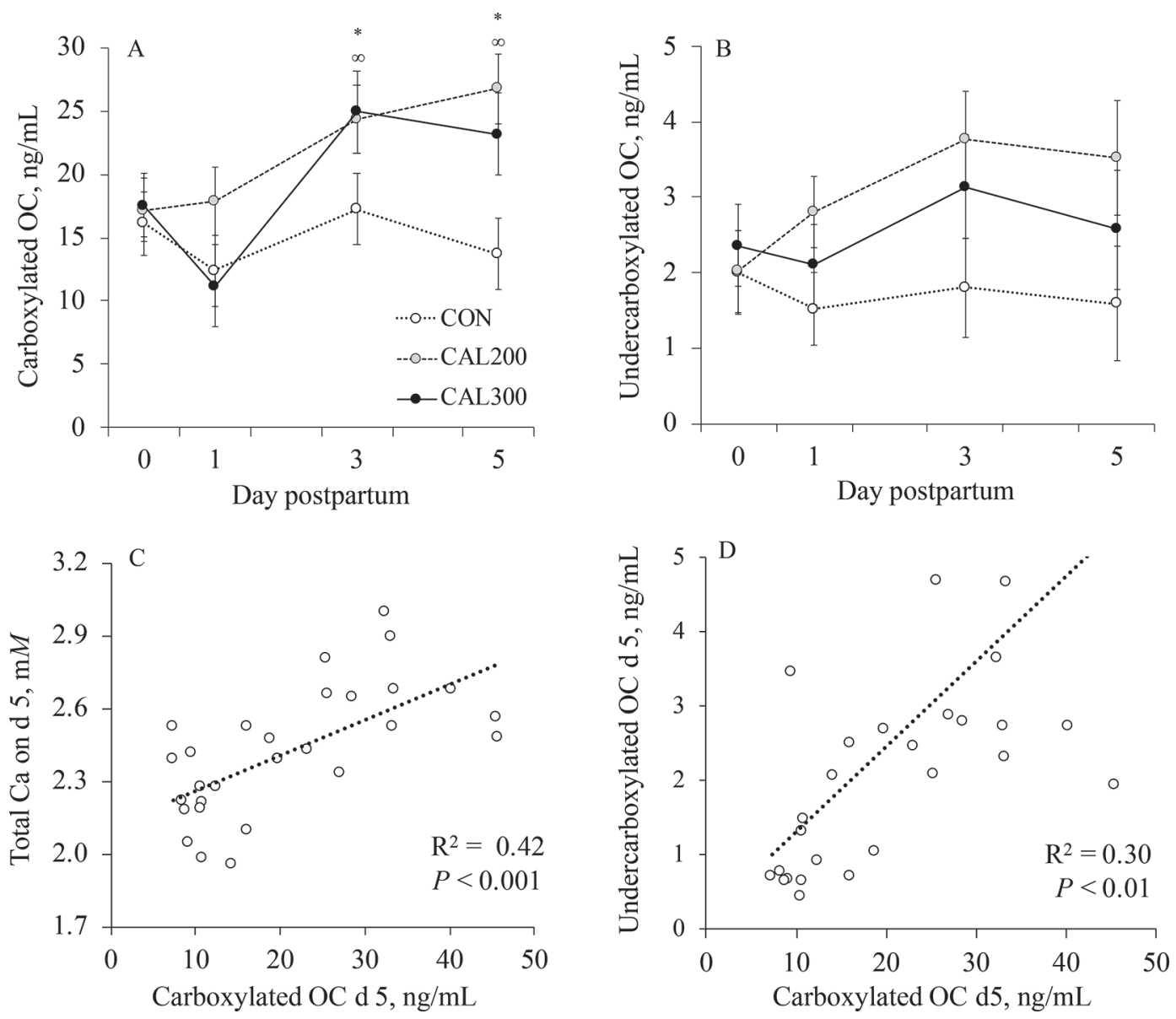

Figure 6. Concentrations of carboxylated (A) and undercarboxylated osteocalcin (OC, B) in plasma of dairy cows receiving an injection of $0(\mathrm{CON} ; \mathrm{n}=10), 200$ (CAL200; $\mathrm{n}=10)$, or $300 \mu \mathrm{g}$ (CAL300; $\mathrm{n}=10)$ of $1 \alpha, 25$-dihydroxyvitamin $\mathrm{D}_{3}$ at calving. Regressions between plasma concentrations of total Ca on d 5 (C) or undercarboxylated OC on d 5 (D) and plasma concentrations of carboxylated OC on d 5. (A) Effects of calcitriol $(P<0.01)$, dose of calcitriol $(P=0.21)$, day $(P<0.001)$, and interaction between treatment and day $(P=0.07)$. (B) Effects of calcitriol $(P=0.05)$, dose of calcitriol $(P=0.32)$, day $(P<0.01)$, and interaction between treatment and day $(P=0.57)$. ${ }^{*}$ Within day, CON differs from CAL200 $(P<0.05) ; \infty$ CON differs from CAL300 $(P<0.05)$. Values on d 0 represent the means before treatment implementation and were used as covariates. Error bars depict SEM. The pooled SEM for carboxylated and undercarboxylated OC were 2.8 and 0.6, respectively.

Mortality affected $4.6 \%(62 / 1,350)$ of the cows (Table $2)$. An interaction $(P=0.01)$ between treatment and calving problem was observed for death. Within cows without calving problem, CAL200 reduced $(P=0.02)$ mortality compared with $\mathrm{CON}$ cows $(\mathrm{CON}=3.5$ vs. CAL200 $=1.0$ vs. CAL300 $=2.0 \pm 0.9 \%$; Figure $5 \mathrm{~B}$ ) However, within cows with calving problem, treatment did not affect mortality (Figure 5A). Multiparous cows had greater $(P<0.001)$ mortality than primiparous cows (primiparous $=1.2$ vs. multiparous $=6.3 \pm 0.8 \%$ ).

Altogether, $14.4 \%(195 / 1,350)$ of the cows left the herd by $300 \mathrm{~d}$ postpartum. Treatment with calcitriol tended $(P=0.09)$ to increase removal from the herd compared with CON cows (Table 2). The hazard of leaving the herd by culling or death did not differ $(P$
$=0.20$ ) among treatments (Supplemental Figure S1A, https://doi.org/10.3168/jds.2020-18448).

\section{Carboxylated and Undercarboxylated Osteocalcin}

Concentrations of cOC in plasma did not differ between treatments on d 0 , before treatment administration. Treatment with calcitriol increased $(P=0.003)$ increased concentrations of $\mathrm{cOC}$, and the effects were greater on d 3 and 5 postpartum (Figure 6A). Similar to $\mathrm{cOC}$, treatment with calcitriol increased $(P=$ 0.05 ) concentrations of $\mathrm{uOC}$, but no differences were observed between CAL200 and CAL300 (Figure 6B). The mean concentrations of plasma uOC were 1.64, 3.36 , and $2.61 \pm 0.61 \mathrm{ng} / \mathrm{mL}$ for CON, CAL200, and 
Table 3. Effect of treatment on BCS and reproductive performance

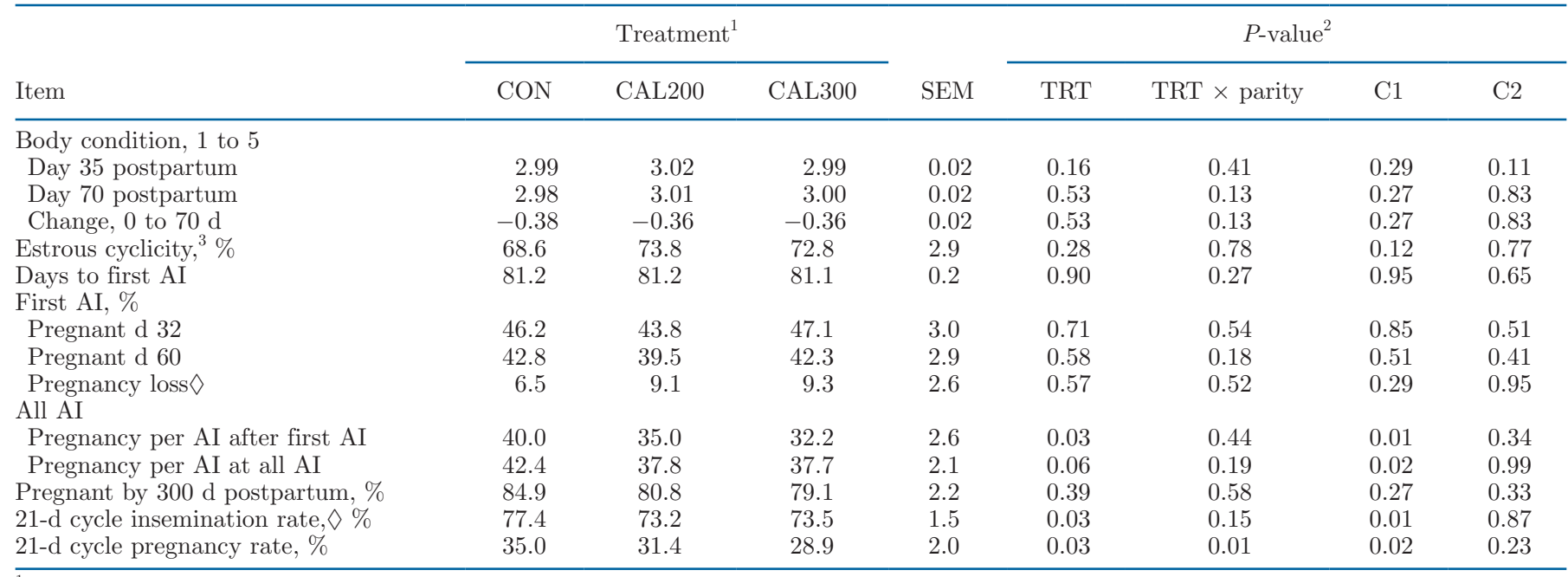

${ }^{1} \mathrm{CON}=$ cows received $0 \mu \mathrm{g}$ of $1 \alpha, 25$-dihydroxyvitamin $\mathrm{D}_{3}$ at calving $(\mathrm{n}=450)$; CAL200 = cows received $200 \mu \mathrm{g}$ of $1 \alpha, 25$-dihydroxyvitamin $\mathrm{D}_{3}$ at calving $(\mathrm{n}=450)$; CAL300 $=$ cows received $300 \mu \mathrm{g}$ of $1 \alpha, 25$-dihydroxyvitamin $\mathrm{D}_{3}$ at calving $(\mathrm{n}=450)$.

${ }^{2} \mathrm{TRT}=$ treatment; $\mathrm{C} 1=$ effect of calcitriol $(\mathrm{CON}$ vs. CAL200 + CAL300); C2 = effect of level of calcitriol (CAL200 vs. CAL300).

${ }^{3}$ Estrous cyclicity by $49 \mathrm{~d}$ postpartum was based on the presence of a corpus luteum in 1 of the ovaries in at least 1 of the 2 ultrasound examinations on $\mathrm{d} 35 \pm 3$ and $49 \pm 3$ postpartum.

$\diamond P<0.05$ for the interaction between treatment and calving problem (dystocia, stillbirth, twins, retained placenta, or vulvovaginal laceration).

CAL300, respectively. Parity group did not affect plasma concentrations of cOC (primiparous $=21.8$ vs. multiparous $=16.4 \pm 2.6 \mathrm{ng} / \mathrm{mL}$ ) or $\mathrm{uOC}$ (primiparous $=2.25$ vs. multiparous $=2.82 \pm 0.54 \mathrm{ng} / \mathrm{mL})$. Positive associations on d 5 postpartum were observed between plasma concentrations of tCa and $\mathrm{cOC}\left(\mathrm{R}^{2}=0.42 ; P\right.$ $<0.001$; Figure $6 \mathrm{C})$ and between $\mathrm{uOC}$ and $\mathrm{cOC}\left(\mathrm{R}^{2}=\right.$ $0.30 ; P<0.001$; Figure 6D).

\section{Milk Yield and BCS}

Treatment with calcitriol did not affect daily milk yield in the first $300 \mathrm{~d}$ postpartum, which averaged $37.8,37.2$, and $37.2 \pm 0.4 \mathrm{~kg} / \mathrm{d}$ for CON, CAL200, and CAL300, respectively. Similarly, cumulative milk yield in the first $60(\mathrm{CON}=2,060$ vs. CAL200 $=2,043$ vs. CAL300 $=2,008 \pm 34 \mathrm{~kg})$ or $300 \mathrm{~d}$ postpartum $(\mathrm{CON}$ $=10,560$ vs. CAL $200=10,330$ vs. CAL300 $=10,237 \pm$ $179 \mathrm{~kg}$ ) did not differ among treatments (Supplemental Figure S2, https://doi.org/10.3168/jds.2020-18448). Treatment with calcitriol or dose of calcitriol did not affect the body condition or the change in BCS in the first $70 \mathrm{~d}$ postpartum (Table 3 ).

\section{Reproduction}

Treatment did not affect resumption of ovarian cyclicity by $49 \mathrm{~d}$ postpartum that was detected in $77.1 \%(998 / 1,295)$ of the cows (Table 3$)$. A smaller ( $P$ $<0.001)$ proportion of primiparous than multiparous cows resumed ovarian cyclicity by $49 \mathrm{~d}$ postpartum (primiparous $=57.7$ vs. multiparous $=82.6 \pm 2.7 \%$ ) .

Cows were synchronized for timed AI for first AI; thus, days to first postpartum AI did not differ among treatments. Pregnancy per AI at first AI, evaluated 32 or $60 \mathrm{~d}$ after insemination, did not differ among treatments (Table 3). An interaction $(P<0.05)$ between treatment and calving problem was observed for pregnancy loss between 32 and $60 \mathrm{~d}$ after first AI (Figure 5). For cows with calving problems, treatment with calcitriol did not affect pregnancy loss (Figure 5A), whereas, for those without calving problems, treatment with calcitriol increased $(P=0.05)$ pregnancy loss (Figure 5B).

Pregnancy per AI for all AI decreased $(P=0.02)$ in cows treated with calcitriol because of a reduction $(P=0.01)$ in pregnancy per AI observed in inseminations after the first postpartum AI (Table 3). Although the proportion of pregnant cows by $300 \mathrm{~d}$ postpartum did not differ among treatments, the 21-d cycle rates of insemination and pregnancy were both lower $(P \leq$ 0.02 ) in cows treated with calcitriol (Table 3 ). In fact, treatment with CAL200 reduced (adjusted hazard rate $=0.86 ; 95 \% \mathrm{CI}=0.74$ to $0.99 ; P=0.04)$ and that of CAL300 tended to reduce (adjusted hazard rate $=$ $0.89 ; 95 \% \mathrm{CI}=0.77$ to $1.03 ; P=0.10$ ) the hazard of pregnancy compared with CON cows (Supplemental Figure S1B, https://doi.org/10.3168/jds.2020-18448). The higher rate of pregnancy for CON cows after first AI resulted in 14 fewer median days open for CON (106 
d; $95 \% \mathrm{CI}=102$ to 120$)$ than for CAL200 (120 d; $95 \%$ $\mathrm{CI}=106$ to 123 ), but no difference was observed for CAL300 (106 d; 95\% CI = 103 to 121).

\section{DISCUSSION}

Administration of the vitamin $\mathrm{D}$ active hormone 1 $\alpha, 25$-dihydroxyvitamin $\mathrm{D}_{3}$ within $6 \mathrm{~h}$ of parturition was successful in inducing a transient increase in plasma calcitriol, observed within the first $24 \mathrm{~h}$ after treatment, which lasted for the first $3 \mathrm{~d}$ postpartum, achieving similar physiological concentrations to those observed in postpartum multiparous cows (Reinhardt et al., 2011) or in cows with clinical hypocalcemia (Horst et al., 1994). This led to increases in concentrations of blood iCa and plasma tCa for $5 \mathrm{~d}$ and increased concentrations of plasma tP for $7 \mathrm{~d}$. Consequently, prevalence of SCH decreased during the first $5 \mathrm{~d}$ postpartum. Hence, it was expected that calcitriol would be beneficial to animal performance. However, positive effects of calcitriol on health depended on presence or not of a calving problem or BCS at calving. Incidence of retained placenta, puerperal metritis, and morbidity decreased in overconditioned cows treated with calcitriol. Similarly, calcitriol reduced death only in cows not diagnosed with calving problems. On the other hand, calcitriol reduced rate of pregnancy in cows because of reduction in insemination rate and pregnancy per AI after the first postpartum insemination. Thus, these results show that potential benefits of treating cows with calcitriol immediately after calving are observed only in some cohorts of cows.

Calcitriol reduced the prevalence of $\mathrm{SCH}$ within the first $5 \mathrm{~d}$ postpartum. Clinical and subclinical hypocalcemia have been associated with increased risk of dystocia (Curtis et al., 1983), retained placenta (Melendez et al., 2004), metritis (Martinez et al., 2012), and uterine prolapse (Risco et al., 1984). The link between $\mathrm{SCH}$ and disease is, in part, related to changes in blood $\mathrm{Ca}$ that reduced available iCa to activate innate immune cells, because Ca directly affects neutrophil function as a key regulator of respiratory burst and degranulation (Burgos et al., 2011). Induction of SCH in dairy cows reduced the concentration of cytosolic iCa in neutrophils and impaired phagocytosis and oxidative burst (Martinez et al., 2014). In fact, cows that develop uterine disease have impaired neutrophil oxidative burst (Hammon et al., 2006), and cows with SCH have reduced neutrophil function and increased risk of metritis (Martinez et al., 2012). Previous work using a similar treatment showed that calcitriol increased blood iCa and improved neutrophil phagocytosis and oxidative burst (Vieira-Neto et al., 2017). Therefore, it was expected that calcitriol treatment would reduce the risk of early-postpartum diseases. Our findings, however, showed that benefits of calcitriol to health of cows varied with the cohort treated.

The daily prevalence of $\mathrm{SCH}$, based on $\mathrm{tCa}<2.15$ $\mathrm{m} M$, in CON cows was relatively low, less than $30 \%$ in any day in the first $5 \mathrm{~d}$ postpartum, and only $15.7 \%$ of the CON cows were diagnosed with $\mathrm{SCH}$ when the threshold was $2.0 \mathrm{~m} M$. Others have shown that hypocalcemia affected more than $45 \%$ of the cows in the first $2 \mathrm{~d}$ postpartum, which is 3 times greater than the incidence observed herein in CON cows. It is possible that preventative measures in place, with feeding an acidogenic diet prepartum, reduced the challenge with $\mathrm{Ca}$ homeostasis in untreated cows and limited the potential benefit of treatment of cows with calcitriol.

Overconditioned cows showed improved health performance when treated with calcitriol. Those cows presented less incidence of retained placenta and puerperal metritis and, consequently, morbidity when receiving calcitriol. It has been suggested that overconditioned cows are at greater risk of developing clinical hypocalcemia (Heuer et al., 1999), which might, in part, explain the benefits of treating them at calving with calcitriol. Overconditioned cows also have reduced appetite compared with cows calving with moderate BCS, and both excessive BCS and reduced intake are risk factors for peripartum diseases, which often affect blood Ca concentrations.

Adipose tissue remodeling is induced by hormonal changes around parturition, and lipolysis is favored over lipogenesis. The increased demand for nutrients during early lactation results in a period of negative nutrient balance, which further stimulates lipolysis and adipose tissue infiltration by innate immune cells, mainly macrophages (Contreras et al., 2015). In obese rodents, macrophages within adipose tissue increased 4 -fold compared with lean rodents (Weisberg et al., 2003). Immune system activation is a costly process in terms of glucose utilization (Kvidera et al., 2017), and diseases often induce hypocalcemia because of loss of vascular $\mathrm{Ca}$ to the interstitial space (Carlstedt et al., 2000), with limited increase in urinary loss of $\mathrm{Ca}$ (Meurer and Höcherl, 2019). Perhaps the greater risk for hypocalcemia suggested in overconditioned cows is, in part, attributable to the greater risk of diseases of inflammatory nature that result in loss of $\mathrm{Ca}$ and, therefore, increased risk of hypocalcemia. Also, overconditioned cows have less appetite, which could compromise $\mathrm{Ca}$ intake in the first day of lactation. The reduction in the prevalence of $\mathrm{SCH}$ in calcitriol-treated cows relative to CON was of greater extent in cows with high BCS. Thus, concentrations of tCa in overconditioned cows benefited more from calcitriol than did concentrations of tCa in cows with $\mathrm{BCS} \leq 3.50$, which might explain 
the reduced incidence of uterine diseases and morbidity observed in overconditioned cows.

The mitochondrial enzyme CYP24A1 controls catabolic hydroxylation of $\mathrm{C}_{23}$ and $\mathrm{C}_{24}$ of $1 \alpha, 25$ dihydroxyvitamin $\mathrm{D}_{3}$. As a tightly regulated mechanism, vitamin $\mathrm{D}$ receptor strongly stimulates $C Y P 24 A 1$ expression; thus, degradation of 25-hydroxyvitamin $\mathrm{D}_{3}$ and $1 \alpha, 25$-dihydroxyvitamin $\mathrm{D}_{3}$ increases, and concentrations of those vitamins are kept under physiological conditions (Tanaka et al., 1977). Exogenous administration of calcitriol in cows increased plasma concentration of the metabolite 24,25-dihydroxyvitamin $\mathrm{D}_{3}$ (VieiraNeto et al., 2017), likely by the activity of CYP24A1. Thus, the reduction observed in concentration of plasma 25-hydroxyvitamin $\mathrm{D}_{3}$, particularly in cows in CAL300, was probably caused by increased catabolism of vitamin D metabolites induced by calcitriol treatment. Although the concentration of 25-hydroxyvitamin $\mathrm{D}_{3}$ required for proper immune function is still debated, it has been suggested that values below $30 \mathrm{ng} / \mathrm{mL}$ might impair immune function in dairy cows (Nelson et al., 2016). It has been demonstrated that 25-hydroxyvitamin $\mathrm{D}_{3}$ has less affinity to the vitamin $\mathrm{D}$ receptor than does $1 \alpha, 25$-dihydroxyvitamin $\mathrm{D}_{3}$, which is the key regulator of vitamin D responsive genes; however, 25-hydroxyvitamin $\mathrm{D}_{3}$ may be an important substrate for local synthesis of $1 \alpha, 25$-dihydroxyvitamin $\mathrm{D}_{3}$ in innate immune cells distributed in tissues with an infection (Nelson et al., 2012), such as leukocytes that fight mastitis and metritis. Also, $1 \alpha, 25$-dihydroxyvitamin $\mathrm{D}_{3}$ is known to downregulate expression of $C Y P 27 B 1$, the enzyme that adds a hydroxyl group to $\mathrm{C}_{1}$ of 25 -hydroxyvitamin $\mathrm{D}_{3}$ to form $1 \alpha, 25$-dihydroxyvitamin $\mathrm{D}_{3}$, resulting in a negative feedback loop. Exogenous administration of calcitriol resulted in a slight increase in the prevalence of $\mathrm{SCH}$ on d 11 postpartum, which might be related to a repression of $C Y P 27 B 1$ expression or activity, as suggested by Littledike and Horst (1982) in cows receiving large doses of vitamin $\mathrm{D}_{3}$.

Primiparous cows had smaller concentrations of 1 $\alpha, 25$-dihydroxyvitamin $\mathrm{D}_{3}$ in plasma than multiparous cows in the first $11 \mathrm{~d}$ postpartum, despite the same dose of calcitriol administered as CAL200 or CAL300 to cows of different sizes. One would assume that the same dose administered to cows would result in increased concentrations in plasma in primiparous than multiparous because of the smaller body size. However, exogenous $1 \alpha, 25$-dihydroxyvitamin $\mathrm{D}_{3}$ clears from blood after $3 \mathrm{~d}$ of treatment (Vieira-Neto et al., 2017), and the endogenous $1 \alpha, 25$-dihydroxyvitamin $\mathrm{D}_{3}$ increases in cows with lower blood iCa, typically older cows. Furthermore, $33 \%$ of the cows analyzed were CON, which never received any exogenous 1 1 ,25-dihydroxyvitamin $\mathrm{D}_{3}$.

Journal of Dairy Science Vol. 104 No. 1, 2021
Bone and energy metabolism are interconnected. This association was demonstrated in a murine model in which osteocalcin was shown to regulate glucose metabolism by improving insulin release by pancreatic B cells (Lee et al., 2007). Undercarboxylated osteocalcin is produced by osteoblasts and can undergo posttranslational modification in which a carboxylation of glutamic acid residue occurs, resulting in $\mathrm{cOC}$, the most abundant form of osteocalcin. Osteocalcin carboxylation occurs within the osteoblast before being secreted into the bone extracellular matrix. However, both forms of osteocalcin can reach the bloodstream and are positively correlated, as also observed in our data (Figure 4D). In fact, recombinant $\mathrm{uOC}$ produced in bacteria, which lacks the gamma carboxylase enzyme, was able to induce insulin expression in pancreas cells. Thus, uOC is the key form to regulate energy metabolism (Ferron et al., 2008), whereas cOC is a marker for bone formation, as circulating cOC derives from bone synthesis (osteoblast activity) rather than breakdown of bone matrix (Price et al., 1981). Calcitriol treatment increased concentrations of both forms of osteocalcin, cOC and uOC. In addition, calcitriol treatment did not affect concentrations of the bone degradation marker CTX-1 in dairy cows in early lactation (Vieira-Neto et al., 2017), which naturally increases with the onset of lactation because of bone resorption (Liesegang et al., 2000; Vieira-Neto et al., 2017). Thus, the increased concentration of osteocalcin in calcitriol-treated cows may be a result of increased osteoblast activity - that is,

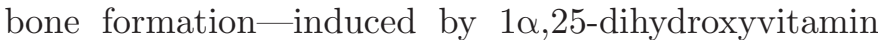
$\mathrm{D}_{3}$ and increased availability of $\mathrm{Ca}$ in the bloodstream as a result of increased gastrointestinal uptake of $\mathrm{Ca}$ led by calcitriol treatment. This is further supported by the positive association observed between concentration of plasma tCa and concentration of plasma cOC (Figure $4 \mathrm{C})$.

Although calcitriol treatment increased plasma tCa and reduced SCH, no benefit was observed in reproductive performance. In fact, the hazard of pregnancy after first AI decreased in cows that received calcitriol. Association between SCH and impaired reproductive performance has been shown in several epidemiological studies (Chapinal et al., 2012; Martinez et al., 2012; Caixeta et al., 2017). Cows with plasma concentrations of tCa below $2.15 \mathrm{mM}$ during all of the first 3 d postpartum had reduced hazard of resumption of postpartum ovulation, reduced pregnancy at first AI, and reduced hazard of pregnancy in the first $120 \mathrm{~d}$ postpartum (Caixeta et al., 2017). Moreover, normocalcemic cows tended to have $61 \%$ faster rate of pregnancy compared with $\mathrm{SCH}$ cows, which resulted in a reduction in median days open of $15 \mathrm{~d}$ (Martinez et al., 2012). Finally, cows with plasma tCa greater than 2.20 
$\mathrm{m} M$ during the first week postpartum had 1.3 times the odds of conceiving at first postpartum AI (Chapinal et al., 2012). It is interesting that calcitriol-treated cows had less SCH, but reproduction was not improved. In fact, after the first AI, measures of reproductive performance were negatively affected by calcitriol, which led to a reduced hazard of pregnancy. Most literature linking $\mathrm{Ca}$ homeostasis and reproductive performance are based on association studies, and it is possible that a causal relationship might not be present. Interventions at calving with supplemental oral Ca have failed to improve reproductive performance in dairy cows (Miltenburg et al., 2016; Leno et al., 2018) or have had mixed effects, with benefits in multiparous but detrimental effects on primiparous cows (Martinez et al., 2016).

For cows without calving problems, those treated with CAL200 had reduced death but increased culling compared with CON. The reduction in death might be related to improved concentrations of Ca postpartum, reduced $\mathrm{SCH}$, or, perhaps, reduced severity or duration of diseases. We can only speculate about this, because severity and duration of diseases were not evaluated in the present experiment. However, the increased culling in CAL200 compared with CON within those without calving problems might be related to the negative effects of calcitriol on reproduction, as observed after the first AI. Perhaps the reduced rate of pregnancy observed after $100 \mathrm{~d}$ postpartum influenced decisions to sell cows.

Colostrum yield is a major risk factor for hypocalcemia, as shown by Goff et al. (2002), who demonstrated that removal of the mammary gland blunted the decrease in plasma tCa at calving, and by the fact that multiparous cows, which produce more colostrum than primiparous cows, also have increased risk of hypocalcemia (Reinhardt et al., 2011; Rodney et al., 2018). Nevertheless, $\mathrm{SCH}$ in the first week postpartum has been associated with less milk yield in the first month of lactation (Chapinal et al., 2012). Furthermore, $\mathrm{SCH}$ is a risk factor for numerous diseases linked to reduced milk yield (Martinez et al., 2012). Thus, it was hypothesized that calcitriol treatment would improve subsequent milk production by increasing availability of $\mathrm{Ca}$ and reducing incidence of diseases during the postpartum period. In spite of the increases in plasma tCa, treatment with calcitriol had no effect on milk yield in the first 60 or $300 \mathrm{~d}$ postpartum. The effects of calcitriol on health of postpartum cows was restricted to those with high BCS at calving, a group representing $20 \%$ of cows enrolled in the experiment (270 out of $1,350)$, and no interaction was observed for treatment and BCS at enrollment on milk yield. Thus, the improvements to health in overconditioned cows were not sufficient to influence milk yield in those cows.
Others have evaluated a multitude of strategies to mitigate hypocalcemia and evaluated productive performance. Feeding acidogenic diets prepartum to reduce the risk of hypocalcemia improved blood tCa concentrations and milk yield in multiparous cows (Santos et al., 2019). However, when cows received oral (Martinez et al., 2016; Leno et al., 2018) or injectable bolus of Ca (Miltenburg et al., 2016), or were treated with injectable calcitriol at calving (Vieira-Neto et al., 2017), SCH decreased, but effects on milk yield were either absent or restricted to subgroups of cows. Therefore, it seems that strategies to minimize the risk of $\mathrm{SCH}$ applied after calving do not necessarily result in improvements in lactation performance, and, when they do, the benefit is restricted to subgroups of cows.

\section{CONCLUSIONS}

Administration of 1 $\alpha, 25$-dihydroxyvitamin $\mathrm{D}_{3}$ within $6 \mathrm{~h}$ of parturition successfully induced an acute and transient increase in concentrations of calcitriol in plasma for the first $3 \mathrm{~d}$ postpartum, which resulted in a sustained increase in plasma concentrations of $\mathrm{iCa}, \mathrm{tCa}$, and $\mathrm{tP}$ in the first $5 \mathrm{~d}$ postpartum. Thus, cows treated with calcitriol had reduced risk of SCH. Although calcitriol treatment reduced the daily prevalence and incidence of $\mathrm{SCH}$, these were relatively low in control cows, and health performance was improved by calcitriol only in overconditioned cows. No benefits to milk yield were observed from treating cows with calcitriol. Pregnancy at first postpartum AI was unaffected by treatment; however, the rate of insemination and the pregnancy per AI after first AI were both lower in cows treated with calcitriol, resulting in a reduced hazard of pregnancy by $300 \mathrm{~d}$ postpartum. Collectively, results from the current experiment indicate that treatment

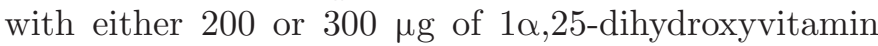
$\mathrm{D}_{3}$ immediately after calving is an alternative method to reduce hypocalcemia, but health benefits depend on the cohort of cows treated. A better understanding of cohorts of cows that benefit from calcitriol and the subsequent reduction in hypocalcemia is needed, to implement such pharmacological interventions to improve Ca homeostasis postpartum and avoid potential detrimental effects.

\section{ACKNOWLEDGMENTS}

The authors thank owners and staff of Alliance Dairies (Trenton, FL), in particular Nilo Francisco, for assistance with the experiment. Financial support for this experiment was provided by a grant from the Southeast Milk Check-Off Dairy Research and Education Projects 
(Southeast Milk Inc., Belleview, FL). The authors have not stated any conflicts of interest.

\section{REFERENCES}

Al-Eknah, M. M., and D. E. Noakes. 1989. A preliminary study on the effect of induced hypocalcaemia and nifedipine on uterine activity in the periparturient cow. J. Vet. Pharmacol. Ther. 12:237-239. https://doi.org/10.1111/j.1365-2885.1989.tb00666.x.

Bicalho, R. C., K. N. Galvão, C. L. Guard, and J. E. P. Santos. 2008. Optimizing the accuracy of detecting a functional corpus luteum in dairy cows. Theriogenology 70:199-207. https://doi.org/10 .1016/j.theriogenology.2008.03.015.

Burgos, R. A., I. Conejeros, M. A. Hidalgo, D. Werling, and C. Hermosilla. 2011. Calcium influx, a new potential therapeutic target in the control of neutrophil-dependent inflammatory diseases in bovines. Vet. Immunol. Immunopathol. 143:1-10. https://doi.org/ 10.1016/j.vetimm.2011.05.037.

Caixeta, L. S., P. A. Ospina, M. B. Capel, and D. V. Nydam. 2017. Association between subclinical hypocalcemia in the first 3 days of lactation and reproductive performance of dairy cows. Theriogenology 94:1-7. https://doi.org/10.1016/j.theriogenology.2017.01 .039 .

Carlstedt, F., M. Eriksson, R. Kiiski, A. Larsson, and L. Lind. 2000. Hypocalcemia during porcine endotoxemic shock: Effects of calcium administration. Crit. Care Med. 28:2909-2914. https://doi .org/10.1097/00003246-200008000-00037.

Chapinal, N., M. E. Carson, S. J. LeBlanc, K. E. Leslie, S. Godden, M. Capel, J. E. P. Santos, M. W. Overton, and T. F. Duffield. 2012. The association of serum metabolites in the transition period with milk production and early-lactation reproductive performance. J. Dairy Sci. 95:1301-1309. https://doi.org/10.3168/jds.2011-4724.

Contreras, G. A., E. Kabara, J. Brester, L. Neuder, and M. Kiupel. 2015. Macrophage infiltration in the omental and subcutaneous adipose tissues of dairy cows with displaced abomasum. J. Dairy Sci. 98:6176-6187. https://doi.org/10.3168/jds.2015-9370.

Curtis, C. R., H. N. Erb, and C. J. Sniffen. 1983. Association of parturient hypocalcemia with eight periparturient disorders in Holstein cows. J. Am. Vet. Med. Assoc. 183:559-561.

Elanco Animal Health. 2009. The 5-point body condition scoring system. Bulletin AI 10752. Elanco Animal Health, Greenfield, IN.

Ferron, M., E. Hinoi, G. Karsenty, and P. Ducy. 2008. Osteocalcin differentially regulates $\beta$ cell and adipocyte gene expression and affects the development of metabolic diseases in wild-type mice. Proc. Natl. Acad. Sci. USA 105:5266-5270. https://doi.org/10 $.1073 /$ pnas.0711119105.

Goff, J. P., R. L. Horst, D. C. Beitz, and E. T. Littledike. 1988. Use of 24-F1-,25-dihydroxyvitamin $\mathrm{D}_{3}$ to prevent parturient paresis in dairy cows. J. Dairy Sci. 71:1211-1219. https://doi.org/10.3168/ jds.S0022-0302(88)79676-9.

Goff, J. P., K. Kimura, and R. L. Horst. 2002. Effect of mastectomy on milk fever, energy, and vitamins A, E, and beta-carotene status at parturition. J. Dairy Sci. 85:1427-1436. https://doi.org/10.3168/ jds.S0022-0302(02)74210-0.

Hammon, D. S., I. M. Evjen, T. R. Dhiman, J. P. Goff, and J. L. Walters. 2006. Neutrophil function and energy status in Holstein cows with uterine health disorders. Vet. Immunol. Immunopathol. 113:21-29. https://doi.org/10.1016/j.vetimm.2006.03.022.

Heuer, C., Y. H. Schukken, and P. Dobbelaar. 1999. Postpartum body condition score and results from the first test day milk as predictors of disease, fertility, yield, and culling in commercial dairy herds. J. Dairy Sci. 82:295-304. https://doi.org/10.3168/jds.S0022 -0302(99)75236-7.

Horst, R. L., J. P. Goff, and T. A. Reinhardt. 1994. Calcium and vitamin D metabolism in dairy cow. J. Dairy Sci. 77:1936-1951. https: //doi.org/10.3168/jds.S0022-0302(94)77140-X.

Kim, D., Y. Kawakami, N. Yamagishi, I. Abe, K. Furuhama, B. Devkota, N. Okura, S. Sato, and S. Ohashi. 2011. Response of plasma bone markers to a single intramuscular administration of calcitriol in dairy cows. Res. Vet. Sci. 90:124-126. https://doi.org/ 10.1016/j.rvsc.2010.05.007.

Kimura, K., T. A. Reinhardt, and J. P. Goff. 2006. Parturition and hypocalcemia blunts calcium signals in immune cells of dairy cattle. J. Dairy Sci. 89:2588-2595. https://doi.org/10.3168/jds.S0022 -0302(06)72335-9.

Kvidera, S. K., E. A. Horst, M. Abuajamieh, E. J. Mayorga, M. V. Sanz Fernandez, and L. H. Baumgard. 2017. Glucose requirements of an activated immune system in lactating Holstein cows. J. Dairy Sci. 100:2360-2374. https://doi.org/10.3168/jds.2016-12001.

LeBlanc, S. J., T. F. Duffield, K. E. Leslie, K. G. Bateman, G. P. Keefe, J. S. Walton, and W. H. Johnson. 2002. Defining and diagnosing postpartum clinical endometritis and its impact on reproductive performance in dairy cows. J. Dairy Sci. 85:2223-2236. https://doi.org/10.3168/jds.S0022-0302(02)74302-6.

Lee, N. K., H. Sowa, E. Hinoi, M. Ferron, J. D. Ahn, C. Confavreux, R. Dacquin, P. J. Mee, M. C. McKee, D. Y. Jung, Z. Zhang, J. K. Kim, F. Mauvais-Jarvis, P. Ducy, and G. Karsenty. 2007. Endocrine regulation of energy metabolism by the skeleton. Cell 130:456-469. https://doi.org/10.1016/j.cell.2007.05.047.

Leno, B. M., R. C. Neves, I. M. Louge, M. D. Curler, M. J. Thomas, T. R. Overton, and J. A. A. McArt. 2018. Differential effects of a single dose of oral calcium based on postpartum plasma calcium concentration in Holstein cows. J. Dairy Sci. 101:3285-3302. https: //doi.org/10.3168/jds.2017-13164.

Liesegang, A., R. Eicher, M. L. Sassi, J. Risteli, M. Kraenzlin, J. L. Riond, and M. Wanner. 2000. Biochemical markers of bone formation and resorption around parturition and during lactation in dairy cows with high and low standard milk yields. J. Dairy Sci 83:1773-1781. https://doi.org/10.3168/jds.S0022-0302(00)75048 $-\mathrm{X}$.

Littledike, E. T., and R. L. Horst. 1982. Vitamin $\mathrm{D}_{3}$ toxicity in dairy cows. J. Dairy Sci. 65:749-759. https://doi.org/10.3168/jds.S0022 $-0302(82) 82263-7$.

Martinez, N., C. A. Risco, F. S. Lima, R. S. Bisinotto, L. F. Greco, E. S. Ribeiro, F. Maunsell, K. Galvão, and J. E. P. Santos. 2012. Evaluation of peripartal calcium status, energetic profile, and neutrophil function in dairy cows at low or high risk of developing uterine disease. J. Dairy Sci. 95:7158-7172. https://doi.org/10 $.3168 /$ jds.2012-5812.

Martinez, N., L. D. P. Sinedino, R. S. Bisinotto, R. Daetz, C. A. Risco, K. N. Galvão, W. W. Thatcher, and J. E. P. Santos. 2016. Effects of oral calcium supplementation on productive and reproductive performance in Holstein cows. J. Dairy Sci. 99:8417-8430. https:/ /doi.org/10.3168/jds.2015-10529.

Martinez, N., L. D. P. Sinedino, R. S. Bisinotto, E. S. Ribeiro, G. C. Gomes, F. S. Lima, L. F. Greco, C. A. Risco, K. N. Galvao, D. Taylor-Rodriguez, J. P. Driver, W. W. Thatcher, and J. E. P. Santos. 2014. Effect of induced subclinical hypocalcemia on physiological responses and neutrophil function in dairy cows. J. Dairy Sci. 97:874-887. https://doi.org/10.3168/jds.2013-7408.

McLaughlin, C. L., E. Stanisiewski, M. J. Lucas, C. P. Cornell, J. Watkins, L. Bryson, J. K. S. Tena, J. Hallberg, and J. R. Chenault. 2012. Evaluation of two doses of ceftiofur crystalline free acid sterile suspension for treatment of metritis in lactating dairy cows. J. Dairy Sci. 95:4363-4371. https://doi.org/10.3168/jds.2011-5111.

Megahed, A. A., M. W. H. Hiew, S. A. El Badawy, and P. D. Constable. 2018. Plasma calcium concentrations are decreased at least 9 hours before parturition in multiparous Holstein-Friesian cattle in a herd fed an acidogenic diet during late gestation. J. Dairy Sci. 101:1365-1378. https://doi.org/10.3168/jds.2017-13376.

Melendez, P., G. A. Donovan, C. A. Risco, and J. P. Goff. 2004. Plasma mineral and energy metabolite concentration in dairy cows fed an anionic prepartum diet that did or did not have retained fetal membranes after parturition. Am. J. Vet. Res. 65:1071-1076. https://doi.org/10.2460/ajvr.2004.65.1071.

Meurer, M., and K. Höcherl. 2019. Endotoxaemia differentially regulates the expression of renal $\mathrm{Ca}^{2+}$ transport proteins in mice. Acta Physiol. (Oxf.) 225:e13175. https://doi.org/10.1111/apha.13175.

Miltenburg, C. L., T. F. Duffield, D. Bienzle, E. L. Scholtz, and S. J. LeBlanc. 2016. Randomized clinical trial of a calcium supplement 
for improvement of health in dairy cows in early lactation. J. Dairy Sci. 99:6550-6562. https://doi.org/10.3168/jds.2016-10961.

NAHMS (National Animal Health Monitoring System). 2014. Dairy cattle management practices in the United States, 2014. United States Department of Agriculture. Accessed Apr. 17, 2019. https: //www.aphis.usda.gov/aphis/ourfocus/animalhealth/monitoring -and-surveillance/nahms/nahms_dairy_studies.

Nelson, C. D., J. L. Powell, D. M. Price, M. J. Hersom, J. V. Yelich, M. E. Drewnoski, S. L. Bird, and G. Allen Bridges. 2016. Assessment of serum 25-hydroxyvitamin D concentrations on beef cows and calves across seasons and geographical locations. J. Anim. Sci. 94:3958-3965. https://doi.org/10.2527/jas.2016-0611.

Nelson, C. D., T. A. Reinhardt, J. D. Lippolis, R. E. Sacco, and B. J. Nonnecke. 2012. Vitamin D signaling in the bovine immune system: A model for understanding human vitamin D requirements. Nutrients 4:181-196. https://doi.org/10.3390/nu4030181.

NRC. 2001. Nutrient Requirements of Dairy Cattle. 7th rev. ed. Natl. Acad. Press, Washington, DC.

Price, P. A., M. K. Williamson, and J. W. Lothringer. 1981. Origin of the vitamin $\mathrm{K}$-dependent bone protein found in plasma and its clearance by kidney and bone. J. Biol. Chem. 256:12760-12766.

Ramberg, C. F. Jr., G. Mayer, D. Kronfeld, J. Phang, and M. Berman. 1970. Calcium kinetics in cows during late pregnancy, parturition, and early lactation. Am. J. Physiol. 219:1166-1177. https://doi .org/10.1152/ajplegacy.1970.219.5.1166.

Reinhardt, T. A., J. D. Lippolis, B. J. McCluskey, J. P. Goff, and R. L. Horst. 2011. Prevalence of subclinical hypocalcemia in dairy herds. Vet. J. 188:122-124. https://doi.org/10.1016/j.tvj1.2010.03.025.

Risco, C. A., J. P. Reynolds, and D. Hird. 1984. Uterine prolapse and hypocalcemia in dairy cows. J. Am. Vet. Med. Assoc. 185:15171519.

Rodney, R. M., N. Martinez, E. Block, L. L. Hernandez, P. Celi, C. D. Nelson, J. E. P. Santos, and I. J. Lean. 2018. Effects of prepartum dietary cation-anion difference and source of vitamin D in dairy cows: Vitamin D, mineral, and bone metabolism. J. Dairy Sci. 101:2519-2543. https://doi.org/10.3168/jds.2017-13737.

Santos, J. E. P., I. J. Lean, H. Golder, and E. Block. 2019. Meta-analysis of the effects of prepartum dietary cation-anion difference on performance and health of dairy cows. J. Dairy Sci. 102:2134-2154. https://doi.org/10.3168/jds.2018-14628.

Souza, A. H., H. Ayres, R. M. Ferreira, and M. C. Wiltbank. 2008. A new presynchronization system (Double-Ovsynch) increases fertility at first postpartum timed AI in lactating dairy cows. Theriogenology 70:208-215. https://doi.org/10.1016/j.theriogenology .2008.03.014.

Tanaka, Y., L. Castillo, H. F. DeLuca, and N. Ikekawa. 1977. The 24-hydroxylation of 1,25-dihydroxyvitamin $\mathrm{D}_{3}$. J. Biol. Chem. 252:1421-1424

Vieira-Neto, A., F. S. Lima, J. E. P. Santos, R. D. Mingoti, G. S. Vasconcellos, C. A. Risco, and K. N. Galvao. 2016. Vulvovaginal laceration as a risk factor for uterine disease in postpartum dairy cows. J. Dairy Sci. 99:4629-4637. https://doi.org/10.3168/jds.2016 -10872 .

Vieira-Neto, A., I. R. P. Lima, F. Lopes Jr., C. Lopera, R. Zimpel, L. D. P. Sinedino, K. C. Jeong, K. Galvão, W. W. Thatcher, C. D. Nelson, and J. E. P. Santos. 2017. Use of calcitriol to maintain postpartum blood calcium and improve immune function in dairy cows. J. Dairy Sci. 100:5805-5823. https://doi.org/10.3168/ jds.2016-12506.

Visek, W. J., R. A. Monroe, E. W. Swanson, and C. L. Comar. 1953. Calcium metabolism in dairy cows as studied with $\mathrm{Ca}^{45}$. J. Dairy Sci. 36:373-384. https://doi.org/10.3168/jds.S0022-0302(53)91506 -9 .

Weisberg, S. P., D. McCann, M. Desai, M. Rosenbaum, R. L. Leibel, and A. W. Ferrante Jr.. 2003. Obesity is associated with macrophage accumulation in adipose tissue. J. Clin. Invest. 112:17961808. https://doi.org/10.1172/JCI200319246. 